\title{
Internal Corporate Investigations
}

\author{
Arthur F. Mathews*
}

\section{INTRODUCTION}

Al Sommer, an esteemed securities lawyer and former commissioner of the Securities and Exchange Commission (SEC), as well as a former law partner of mine, recently made these comments on the development of the internal investigation mechanism utilized with ever-increasing frequency during the past decade by American business:

Internal investigations had been performed before the SEC announced its voluntary disclosure policy in the mid-1970s. But as a result of the Commission's voluntary disclosure program, a larger number of important and publicized investigations were undertaken. The result has been the development of a new institution-the internal investigation - which is an extra-legal institution, because there is no statutory basis for it. There is a broad common-law basis for the proposition that if a corporation senses there has been wrong-doing, management has an obligation to ascertain the extent of it and to pursue a remedy. Nonetheless, there is no statute that directs a corporation to conduct an internal investigation.

Despite the absence of formalized legal support, a set of "laws" has developed around the investigations program initiated by the Commission. A good deal of common practice has developed that can be found in various manuals and articles. Entire congeries of techniques have developed to deal with a problem that requires investigation. It does not necessarily have to be a matter involving securities fraud. Wherever management finds a problem it wants to eradicate effectively and in an objective fashion, it may resort to this new technique of internal investigation. I think this is a very important development in the area of corporate law. ${ }^{1}$

Let me relate to you how I have become familiar with what Al Sommer labels as this extra-legal institution of the internal corporate investigation. I have read much and even written some of the relevant legal literature in the past five or six years. ${ }^{2}$

* Partner, Wilmer, Cutler \& Pickering, Washington, D.C. Formerly Deputy Associate Director (Enforcement), United States Securities and Exchange Commission, Washington, D.C.

1. Sommer, Internal Controls, 61 N.C.L. Rev. 505, 505 (1983).

2. See, e.g., Bialkin, Legal and Practical Considerations For Disclosure of the Results of an Internal Corporate Investigation, in Practising LAW Instrtute, The Internal Corporate Investigation 127-63 (Cotporate Law \& Practice Course Handbook Series No. 333, Block \& Pickholz ed. 1980); Block \& Barton, Internal Corporate Investigations: Maintaining the Confidentiality of a Corporate Client's Communications With Investigative Counsel, 35 Bus. LAW. 5 (1979); Brodsky. The "Zone of Darkness": Special Counsel Investigations and the Attorney-Client Privilege, 8 SEC. REG. L.J. 123 (1980); Fedders, Corporate Criminal Responsibility-Conducting An Internal Investigation, 3 CRIM. Def. TeChNIQUes (MB) ch. 62 (1979); Fedders, Investigative Counsel's Vulnerability, in Practising LAW Institute, The INTERnal Corporate Investigation 295; Gruenbaum \& Oppenheimer, Special Investigative Counsel: Conflicts and Roles, 33 Rutcers L. Rev. 865 (1981); Klein, Conduct of Directors When Litigation Is Commenced Against Management, 31 Bus. LAw. 1355 (1976); Mathews, The Functioning of Directors in "Sensitive Payments Inquiries," in Practising Law Institute, Ninth Annual Institute on Securmies Regulation 83-95 (hardcover ed. 1978); Mathews, Klein, Williams, \& Taylor, The Functioning of Directors in "Sensitive Payments Inquiries," 1 NiNTH ANNUAL Institute ON Securmes Regulation 135-260 (paperback ed. 1977); Pitt, Special Investigative Counsel: The SEC's Independent Police Force or Corporate Representatives? in 1 NEgotIATING SEC CONSENT DECREES: TARGETS And TACtics For Setring Civil Inunctive Actions 142 (A. Mathews ed. 1979); Note, Discovery of Internal Corporate Investigations, 32 STAN. L. REv. 1163 (1980); Comment, Corporate Self-Investigations Under the Foreign 
However, I first began to observe the development of corporate self-investigations as an outgrowth of the increased pace of the SEC's nationwide enforcement program in the early 1960 s.

\section{SEC's 1960s Enforcement Program: The VTR Example}

Over two decades ago in the pre-Sporkin era, when I was a young enforcement attorney in the SEC's Division of Trading and Exchanges, Irv Pollack was the principal architect of the SEC's nationwide enforcement program. ${ }^{3}$ At that time the civil injunctive action was the favored enforcement tool. ${ }^{4}$ But for a leader as creative as Pollack, merely obtaining an injunction was not sufficient to resolve particularly complex, egregious cases. Consequently, the Enforcement staff was encouraged to seek sometimes novel, somewhat exotic additional relief in important civil injunctive actions. Such ancillary relief, as it came to be called, was designed to make victims whole and to restore corporate circumstances to healthier, pre-violation, law-abiding conditions: it was an important supplement to the traditional injunctive order, ${ }^{5}$ which merely deterred future violations. The decade of the 1960s saw SEC civil injunctive enforcement actions request with increasing regularity such ancillary relief. The SEC sought ancillary relief in such forms as appointment of receivers or special agents, restitution or disgorgement of ill-gotten gains, limitations on activities of officers or

Corrupt Practices Act, 47 U. CHI. L. Rev. 803 (1980); Pickholz, Confronting SEC Pressure: A Need For Legal Audits, Legal Times of Wash., Oct. 29, 1979, at 14-15; see also Upjohn Co. v. United States, 449 U.S. 383 (1981); In re Sealed Case (Tesoro Petroleum), 676 F.2d 793 (D.C. Cir. 1982); In re John Doe Corp. (Southland Corp.), 675 F.2d 482 (2d Cir. 1982); Comment, The Attorney-Client Privilege, the Self-Evaluative Report Privilege, and Diversified Industries, Inc. v. Meridith, 40 OнIо ST. L.J. 699 (1979).

3. Irving M. Pollack later became Director of the SEC's Division of Trading and Markets and in that position ran the nationwide enforcement program throughout the 1960 s for the SEC under the chairmanship of Manuel F. Cohen. One of his principal enforcement deputies was Stanley Sporkin. See Mathews \& Klein, Manuel F. Cohen In Perspective: Manny-We Miss Your Sparkle! 46 GEo. WASH. L. REv. 719 (1978). Pollack thereafter became the first Director of the SEC's newly created Division of Enforcement in 1972 and turned the leadership of the enforcement program over completely to Sporkin in 1974 when Pollack was elevated to membership on the Commission itself.

4. See, e.g.. André, The Collateral Consequences of SEC Injunctive Relief: Mild Prophylactic or Perpetual Hazard? 1981 U. ILL. L. REv. 625; Bemporad, Injunctive Relief in SEC Civil Actions: The Scope of Judicial Discretion, 10 Colum. J.L. \& SOC. PROBS. 328 (1974); Harkleroad, Requirements for Injunctive Actions under the Federal Securities Laws, 2 J. CORP. L. 481, (1977); Hazen, Administrative Enforcement: An Evaluation of the Securities and Exchange Commission's Use of Injunctions and Other Enforcement Methods, 31 HASTINGS L.J. 427 (1979); Mathews, SEC Civil Injunctive Actions, 5 Rev. SEC. REg. No. 4 at 969-76 (1972); Mathews, SEC Civil Injunctive Actions II, 5 REv. SEC. REG. No. 6 at 949-56 (1972); Pitt \& Markham, SEC Injunctive Actions, 6 Rev. SEc. ReG. No. 5 at 955-61 (1973); Program of the Committee on Federal Regulation of Securities: SEC Civil Injunctive Actions, 30 Bus. LAW. 1303, 1303-06 (1975).

5. See, e.g., Dent, Ancillary Relief in Federal Securities Law: A Study in Federal Remedies, 67 MINN. L. Rev. 865 (1983); Farrand, Ancillary Remedies in SEC Civil Enforcement Suits, 89 HARv. L. REv. 1779 (1976); Jacobs, Judicial and Administrative Remedies Available to the SEC for Breaches of Rule 10b-5, 53 ST. JoHN's L. REv. 397, 410-21 (1979); Malley, Far-Reaching Equitable Remedies under the Securities Act and the Growth of Federal Corporate Law, 17 WM. \& MARY L. Rev. 47 (1975); Mathews, Over-Use and Abuse of the SEC Civil Injunctive Remedy: Should the Proposed Federal Securities Code Contain an SEC Administrative Cease and Desist Enforcement Remedy? in 1 Negotiating SEC Consent Decrees: TARgets and TACtics For Civil InJunctive Actions 438 (A. Mathews ed. 1979); Mathews, Recent Trends in SEC Requested Ancillary Relief in SEC Civil Injunctive Actions in 1 NeGOTATING SEC Consent DeCrees: Targers and Tactics For Civil Injunctive ACtions 270 (A. Mathews ed. 1979); Mathews, Recent Trends in SEC Requested Ancillary Relief in SEC Civil Injunctive Actions, 31 Bus. LAw. 1323 (1976); Sporkin, SEC Developments in Litigation and the Molding of Remedies, 29 Bus. LAw. 121 (Supp. 1974); Treadway, SEC Enforcement Techniques: Expanding and Exotic Forms of Ancillary Relief, 32 WASH. \& LEE L. Rev. 637 (1975); Note, Ancillary Relief in SEC Injunction Suits for Violation of Rule 10b-5, 79 HARv. L. Rev. 656 (1966); Comment, Equitable Remedies in SEC Enforcement Actions, 123 U. PA. L. REv. 1188 (1975). 
directors, wholesale restructuring of boards of directors, accountings, and restrictions on voting blocs of stock and rescission offers. ${ }^{6}$

I should note, however, that pleas for these novel forms of ancillary relief did not always come from the Commission or its Staff. Sometimes, defense counsel in negotiating an enforcement settlement would offer a new approach in order to avoid unduly severe sanctions posed by the particular ancillary remedy initially sought by the Commission. For example, in a major corporate fraud suit that I litigated for the Commission in 1965 and 1966, SEC v. VTR, Inc., ${ }^{7}$ the SEC sought, in addition to injunctive relief, restitution of over $\$ 1.2$ million from the principal officers and directors of the corporate defendant, as well as appointment of a receiver to assure that corporate affairs would be conducted properly, that all self-dealing would be halted, and that the company's deficient SEC filings would be corrected.

Astute defense counsel, wiser and more experienced than I, were willing to counsel their clients to provide the requested restitution after an appropriate accounting, but refused to consider appointment of a receiver. ${ }^{8}$ Such drastic relief as receivership could well have forced VTR, then a solvent ongoing business with securities listed on the American Stock Exchange, into bankruptcy. Receivership, even when temporary and limited, often triggers defaults in lines of credit, drives away existing and potential customers, and scares employees and agents into seeking new employment. Consequently, innocent public shareholders do not necessarily benefit from a receivership. VTR's able counsel countered the SEC's request for a receiver with an offer to have the district court appoint three new independent directors to constitute a court-supervised majority on the five-person board (one of the new independent directors to serve as chair) and to charge the independent directors to pursue an internal corporate investigation. The court accepted this new approach. ${ }^{9}$

The internal corporate special investigation encompassed the activities of VTR's management embraced in the Commission's complaint. It led to the filing of the mandated accounting with the court and eventually to payment of over $\$ 1.2$ million in disgorgement to rectify or pay off illegal loans to corporate insiders. ${ }^{10}$ The VTR case preceded the now infamous Texas Gulf Sulphur litigation ${ }^{11}$ and was a unique learning experience for me.

There may have been earlier cases of court-ordered internal investigations (apart from traditional investigations by court-appointed receivers or Chapter X bankruptcy

6. See, e.g.. Ellsworth, Disgorgement in Securities Fraud Actions Brought by the SEC, 1977 DuKE L.J. 641 ; Farrand, Ancillary Remedies in SEC Civil Enforcement Suits, 89 HARv. L. Rev. 1779 (1976); Jacobs, supra note 5, at 410-21; Mathews, Recent Trends in SEC Requested Ancillary Relief in SEC Civil Injunctive Actions, 31 Bus. LAw. 1323 (1976); Comment, Court-Appointed Directors: Ancillary Relief in Federal Securities Law Enforcement Actions, 64 GeO. L.J. 737 (1976); Comment, supra note 5.

7. SEC v. VTR, Inc., SEC Lit. Release No. 3311 (S.D.N.Y. 1965); SEC Lit. Release No. 3306 (S.D.N.Y. 1965); SEC Lit. Release No. 3356 (S.D.N.Y. 1965); SEC v. VTR, Inc., 32 SEC Ann. Rep. 116-17 (1966); see SEC v. VTR, Inc., 39 F.R.D. 19 (S.D.N.Y. 1966) [all hereinafter cited as VTR Case].

8. Those defense counsel were Milton S. Gould and Arthur Christy, veterans of many SEC enforcement actions and white-collar criminal cases arising therefrom.

9. VTR Case, supra note 7.

10. Id.

II. SEC v. Texas Gulf Sulphur Co., 401 F.2d 833 (2d Cir. 1968) (en banc). 
reorganization trustees) ${ }^{12}$ in the context of SEC civil injunctive actions, but $V T R$ was my introduction to the field of corporate self-investigations, which has burgeoned during the past 20 years into a useful technique in American corporate life and law.

I left the SEC Enforcement staff in October 1969, a day or two after filing the injunctive complaint in S.E.C. v. Parvin/Dohrmann Co. ${ }^{13}$ which embraced classic Rule 10b-5 violations, market manipulation, and shady "influence peddling" in an attempt by a large, public corporation to cause the SEC to lift a trading suspension. ${ }^{14}$ The Commission eventually settled the case, obtaining, in addition to a traditional injunctive order, various types of ancillary relief against certain individual defendants. Ancillary relief included orders prohibiting certain defendants from continuing to serve as directors of Parvin/Dohrmann without prior SEC approval, requiring defendants to divest themselves of the company's stock, and requiring disgorgement from certain defendants of their ill-gotten gains. ${ }^{15}$

\section{Early 1970s: The Mattel Consent Decree}

Shortly thereafter, in the early 1970 s, in the Ecological Science case, ${ }^{16}$ an SEC injunctive action, the Second Circuit approved a district court order appointing a so-called limited receiver with several powers. The limited receiver was to investigate and issue a public report on certain secret securities transactions, supervise the company's public disclosures, including SEC filings and press releases, and hold a shareholders' meeting to accomplish the election of a new board of directors. ${ }^{17}$ Thus, by the early 1970s, the SEC was gradually learning that an efficacious way to straighten out huge corporate messes brought to surface by some of its major enforcement actions was to restructure boards of directors and cause independent directors or their special counsel to accomplish internal corporate self-investigations, rather than to tie up scarce government resources to do the whole job in each case.

In 1972, 1973, and 1974, Manny Cohen and I had several occasions to utilize what defense counsel had taught me several years earlier in VTR. ${ }^{18}$ In 1972 , in the American Agronomics case, ${ }^{19}$ we negotiated a consent injunction with ancillary relief that provided for a restructuring of the board of directors and a special internal

12. See, e.g., 11 U.S.C. $\$ 1106(a)(4)$ (1982); 2 L. Loss, SeCURITIES Regulation 754-63 (1961); 5 L. Loss, SeCurities Regulation 2688-95 (Supp. 1969).

13. [1969-1970 Transfer Binder] Fed. SEC. L. ReP. (CCH) I 92,500 (S.D.N.Y. Oct. 30, 1969).

14. Id.; see also United States v. Sweig, 316 F. Supp. 1148 (S.D.N.Y. 1970) (criminal proceeding against an agent of Parvin/Dohrmann Co. for conspiracy to defraud United States and for perjury).

15. SEC v. Parvin/ Dohrmann Co., [1969-1970 Transfer Binder] FED. SEC. L. REP. (CCH) q 92,500 (S.D.N.Y. Oct. 30, 1969) (judgment of permanent injunction regarding anti-fraud violations, non-disclosures, and improper corporate purpose), [1969-1970 Transfer Binder] FED. SEC. L. REP. (CCH) I 92,522 (S.D.N.Y. Nov. 18, 1969) (consent judgment regarding exchange of stock and violations of anti-fraud provisions), [1969-1970 Transfer Binder] FED. SEC. $L$. REP. (CCH) I 92,615 (S.D.N.Y. Feb. 16, 1970) (summary of briefs) [all hereinafter cited as Parvin/Dohrmann Case].

16. SEC v. Ecological Science Corp., [1970-1971 Transfer Binder] FED. SEc. L. ReP. (CCH) \{ 93,025 (S.D.N.Y. Apr. 30, 1971); see also Ecological Science Corp. v. SEC, [1972-1973 Transfer Binder] FeD. SEC. L. REP. (CCH) I 93,663 (D.C. Cir. Nov., 1972).

17. SEC v. Koenig (Ecological Science), 469 F.2d 198, 202 (2d Cir. 1972). Cf. United States v. Koenig, 388 F. Supp. 670 (S.D.N.Y. 1974), in which former New York City Mayor Rober Wagner served as the limited receiver. While he served an investigative and monitoring function, he was not charged by the consent decree to take over the management of the corporation from its duly (and newly) elected board of directors.

18. See supra notes 8-10 and accompanying text.

19. SEC v. American Agronomics Corp., SEC Lit. Release No. 5667 (S.D. Ohio 1972). 
investigation. The case dealt with the allegedly fraudulent sale of investment contract interests in orange groves. As ancillary relief the company and its principals agreed to perform the following steps:

1. Engage certified public accountants to conduct a survey of all persons who had purchased grove securities within the prior five years.

2. Within sixty days after the commencement of this survey, the independent certified public accountants were required to furnish to Agronomics and the Commission a report containing a summary of the responses to the survey. That report was then to be submitted to a special counsel appointed by the court and retained by Agronomics, who was to determine, based on the facts before him, if there were any individuals for whom the purchase of an Agronomics investment contract was unsuitable at the time of the purchase. To guide the special counsel in this determination of suitability, the decree set out the following factors: (i) gross income; (ii) net worth; (iii) income tax bracket; (iv) size of investment in grove securities; (v) other investments; (vi) any other relevant circumstances. These factors were to be applied as of time of purchase by the individual orange grove investors.

If the special counsel determined a purchase was unsuitable, the purchaser was to be offered a rescission by Agronomics, including refund of all payments made to Agronomics plus interest and reasonable attorney fees, less any payments received by the grove owners as a result of orange production. Response to the survey and acceptance of an offer of rescission was entirely voluntary on the part of the individual grove owners. In no way did it affect the individual grove owner's rights to seek any legal or equitable relief that might have been available to him.

3. The defendants also were required to take steps to assure that equitable treatment was given to any individual who paid maintenance on an unplanted grove, was shown a grove other than his own, or was paid for orange production that was not produced by his grove.

4. The two individual defendants agreed to deposit with Agronomics 60,000 shares of Agronomics common stock to be used to satisfy any expenses to Agronomics that might arise as a result of any of the conduct alleged in the Commission's complaint and also agreed to pay reasonable expenses in connection with the registration of these shares if registration should become necessary.

5. The Board of Directors of Agronomics was restructured to include at least forty percent independent representation. An accounting committee of the independent directors was to be established. The two individual defendants were prohibited from acting as officers of Agronomics, their salaries as directors and consultants to the corporation were limited to $\$ 35,000$ per year, and in the event either of them severed his employment relationship with Agronomics during the following five years, he became obligated to pay $\$ 12,500$ per year to Agronomics until the end of that period. ${ }^{20}$

In the American Agronomics case the SEC took a giant step toward corporate 
governance through consent decree by extensively restructuring a board of directors, ordering an internal investigation by a special counsel, and other substantive actions.

In 1973, in the Coastal States Gas case, ${ }^{21}$ Manny and I negotiated a consent injunction that included as ancillary relief:

1. The Board of Directors of Coastal States Gas Corporation was increased from ten to thirteen members, with six new independent members satisfactory to the SEC to be designated by the court and elected by Coastal's Board.

2. Additionally, the order provided that Coastal's Board would elect a new Executive Committee to be composed of three members, two of whom would be new members designated by the court and satisfactory to the SEC and the other of whom would be the chair. Independent legal counsel was to be available, at the corporation's expense, to advise the Executive Committee regarding their functions as directors and as members of the Executive Committee and regarding other related matters.

3. The order also provided for the appointment by Coastal of an independent audit committee consisting of three members, a majority of whom were to be new members of the Board.

4. The order further provided that Coastal would request its independent auditors to furnish to the SEC the results of a special review of certain transactions pertaining to the 1971 and 1972 financial statements and in connection therewith to make disclosures and filings as required under applicable laws and regulations in light of the results of such special review. ${ }^{22}$

And in 1974, Manny and I were co-counsel ${ }^{23}$ in the Mattel case, ${ }^{24}$ which has since been dubbed one of the seminal cases in the SEC's intrusion into corporation governance via consent decree. ${ }^{25} \mathrm{Mattel}$ involved a serious fraud implicating certain high level management officials of the company. The SEC's limited investigations had uncovered falsified financial statements which stated millions of dollars of fictitious earnings. Today, SEC Commissioner Treadway would call the case a classic "cooked books" case. ${ }^{26}$

In negotiating a consent injunction in Mattel, Manny and I and our co-counsel

21. SEC v. Coastal States Gas Corp. (Oscar P. Wyatt, Jr.), SEC Lit. Release No. 6054 (S.D. Tex. Sept. 12, 1973) at 2 SEC Docket No. 13 at 451 (Oct. 2, 1973) [hereinafter cited as Coastal States Case].

22. Id. In another injunctive consent decree in 1973, SEC v. Clinton Oil Co., SEC Lit. Release No. 5715 (D. Kan. Jan. 30, 1973) at 1 SEC Docket No. 1 at 28 (Feb. 13, 1975), SEC Lit. Release No. 5798 (D. Kan. Mar. 20, 1973) at 1 SEC Docket No. 8 at 23 (Apr. 3, 1973) [hereinafter cited as Clinton Oil Case], the SEC took a substantial step forward in corporate governance through enforcement: The SEC had the court appoint an entirely new board of directors. The theory was that the old board had been engaged in mismanagement and egregious fraud and had to be completely insulated from the future management of the corporation.

23. Our co-counsel were Dick Borow and Ron Loeb of Irell \& Manella, and Ray Ferris, then General Counsel of Mattel.

24. SEC v. Mattel, Inc., SEC Lit. Release No. 6467 (D.D.C. Aug. 5, 1974) at 4 SEC Docket No. 20 at 724 (Aug. 20, 1974), SEC Lit. Release No. 6531 (D.D.C. Oćt. 2, 1974) at 5 SEC Docket No. 8 at 241 (Oct. 16, 1974), SEC Lit. Release No. 6532 (D.D.C. Oct. 3, 1974) at 5 SEC Docket No. 8 at 242 (Oct. 16, 1974) [hereinafter cited as 1974 Mattel Case]; see also, United States v. Handler, [1978 Transfer Binder] FED. SEC. L. REP. (CCH) I 96,519 (C.D. Cal. Aug. 3, 1978); SEC v. Mattel, No. CV-74-2958-FW (C.D. Cal. 1977) (injunction against disclosure of information by special counsel); Handler v. SEC, 430 F. Supp. 71 (C.D. Dal. 1977), aff d, 610 F.2d 656 (9th Cir. 1979).

25. See, e.g., Comment, Court-Appointed Directors: Ancillary Relief in Federal Securities Law Enforcement Actions, 64 Geo L.J. 737, 738 (1976).

26. Speech by SEC Commissioner James C. Treadway, Jr., before Institute For Corporate Counsel in Los Angeles (March 11, 1983), reprinted as Treadway, Cooked Books: No New Recipes, 30 FeD. BAR News \& J. 323 (1983). 
strived to avoid appointment of a traditional or temporary receiver, which we felt might unfairly drive the company into bankruptcy. We also wanted to avoid the severity of a limited receiver of the type utilized in Ecological Science. In Mattel, the individual members of management allegedly involved in the fraud included certain officer-directors who were unwilling to consent to a bar from serving as directors, as some of the defendants in Parvin/Dohrmann had done. But the Mattel Board qua Board was willing to follow the VTR example by consenting to appointment of a majority of new, unaffiliated directors, approved by the SEC and acceptable to the court, to monitor stewardship of the company. The Board also was willing to submit to even more novel ancillary relief. Aided by the flexibility and ingenuity of Stanley Sporkin and his then assistant Irwin Borowski, we hammered out what was in 1974 a significant SEC consent injunctive decree.

The settlement required that the new independent directors appoint a special counsel satisfactory to the court and the Commission to investigate the allegations embraced by the SEC injunctive complaint, to prepare and file with the SEC a public report thereof, and to recommend to a newly constituted Litigation and Claims Committee (consisting of independent directors) what, if any, causes of action the corporation should pursue against prior management or third parties. The decree also required Mattel to appoint and maintain a new Executive Committee (a majority of the members of which had to be independent directors) and a Financial Controls and Audit Committee (a majority of whose members were independent directors) and required the special counsel to retain a special auditor (an outside independent CPA firm) to report on Mattel's accounting practices. ${ }^{27}$

Seth Hufstetler became special counsel. His performance in the Mattel litigation demonstrated how a large public company could investigate very serious corporate misconduct through the use of an independent, outside counsel and thereby enable the corporation's board of directors to clean its own house, maintain order, and restore the shareholders' faith in the company's capacity to be law-abiding and in the corporation's general business reputation. The novel relief in the Mattel consent decree later survived constitutional and other attacks in both criminal and civil forums. ${ }^{28} \mathrm{In}$ the Mattel litigation, the court specifically acknowledged that "the appointment of Special Counsel is a legally recognized form of ancillary relief" in SEC civil in- junctive actions. ${ }^{29}$ Indeed, the court described appointment of special counsel as a "desirable and economical practice" that "allows the company to keep its own house clean and avoid unnecessary governmental supervision.",30

In 1973, prior to Mattel, Stanley Sporkin had settled a portion of the SEC's litigation against Robert Vesco ${ }^{31}$ through the vehicle of a novel consent decree. If my recollection is correct, it was again Milton Gould (with whom I had dealt in VTR)

27. SEC v. Mattel, Inc., [1974 Transfer Binder] FED. SEC. L. ReP. (CCH) I] 94,754 (D.D.C. Aug. 8, 1974); see also 1974 Mattel Case, supra note 24.

28. Handler v. SEC, 430 F. Supp. 71, 74 (C.D. Cal. 1977), aff d, 610 F.2d 656 (9th Cir. 1979) (civil case challenging consent decree issued in Mattel); United States v. Handler, [1978 Transfer Binder] FeD. SEC. L. REP. (CCH) T 96.519 (C.D. Cal. Aug. 3, 1978) (criminal action against Mattel directors for conspiracy to commit fraud).

29. United States v. Handler, [1978 Transfer Binder] Fed. SEC. L. REP. (CCH) 996,519 (C.D. Cal. Aug. 3, 1978).

30. Id. at 94,024 .

31. SEC v. Vesco [1972-1973 Transfer Binder] Fed. SEC. L. ReP. (CCH) I 93,671 (S.D.N.Y. Nov. 11, 1973). 
who negotiated the International Controls Corp. (ICC) consent decree with Sporkin. The ICC decree provided broad ancillary relief in lieu of the appointment of a receiver for ICC, which the SEC had sought initially. ${ }^{32}$ The relief included appointment of an independent special counsel to conduct a court-monitored investigation, ${ }^{33}$ court appointment of a whole new interim board of directors, and a special counsel with power to pursue all claims on behalf of ICC by instituting all necessary litigation himself, although no claims could be settled without approval of both the SEC and the court. ${ }^{34}$ Thus, the ICC settlement was much more akin to a temporary limited receivership than was the $M a t t e l$ decree.

\section{Watergate and its Aftermath: From Illegal Domestic Political Contributions to Sensitive and Questionable Foreign Payments to Commercial Bribes, Kickbacks and Management Fraud to Undisclosed Corporate Perks}

The Mattel experience, which left the company itself directing the special counsel in accomplishing the internal investigation, pleased both the SEC and the company. The company was realigned and restored to health, for the benefit of all its public shareholders. The SEC utilized the VTR and Mattel types of settlements as models for a potpourri of consent decrees throughout the 1970s. At first, the cases did not fall into any particular pattern. ${ }^{35}$ Then, as particular events caused the SEC's Enforcement Division to tailor special enforcement programs and as changing circumstances dictated shifting enforcement priorities to different programs, the "special investigation" became standard ancillary relief in several enforcement waves. First, commencing in late 1974, came the Watergate domestic campaign contribution cases regarding political slush funds. Second, was the infamous sensitive and questionable foreign payments program, which eventually spawned passage of the Foreign Corrupt Practices Act in late 1977. Third, was a series of cases dealing with illegal domestic kickbacks, commercial bribes, or other questionable, commercial payments generally labelled management fraud. Fourth, was a flurry of cases dealing with undisclosed corporate perquisites-the "perks" cases. ${ }^{36}$

It gradually became rather routine to settle an SEC enforcement case against a major corporation by agreeing to have outside counsel serve as special counsel in conducting an internal corporate investigation on behalf of the company's board of directors or audit committee. Sometimes the settlements required adding new independent directors to the board; sometimes they did not. In almost all cases, the company was required to publicize the special counsel's or audit committee's report

32. See id.; see also International Controls Corp. v. Vesco, 490 F.2d 1334, 1339-40 (2d Cir. 1974).

33. SEC v. Vesco, [1972-1973 Transfer Binder] FED. SEC. L. REP. (CCH) I 93,671 (S.D.N.Y. Nov. 11, 1973); see also Hogan \& Hartson v. Butowsky, 459 F. Supp. 796 (S.D.N.Y. 1978).

34. SEC v. Vesco, [1972-1973 Transfer Binder] Fed. SEC. L. ReP. (CCH) q 93,671 (S.D.N.Y. Nov. 11, 1973). The court-appointed interim board served for several years until a Special Master supervised a new board election. Malhas v. Shinn, 597 F.2d 28 (2d Cir. 1979); SEC v. Vesco, 571 F.2d 129 (2d Cir. 1978).

35. See, e.g., SEC v. Westgate-California Corp., SEC Lit. Release No. 6142 (S.D. Cal. Nov. 9, 1973) at 3 SEC Docket No. 1 at 30 (Nov. 20, 1973).

36. See, e.g., Mathews \& Thompson, SEC [1978] Enforcement Program Focuses on Payments And Perquisites, SEC '79, at 15 (1979). 
of investigation or a summary thereof. For example, two days after the Mattel settlement, the SEC filed a consent decree in the American Ship Building (AmShip) case ${ }^{37}$ the first domestic illegal campaign contributions case. The consent order embraced the following ancillary relief:

The order also requires the defendant American Ship Building Company to establish a Special Review Committee consisting of a chairman not affiliated with the company and at least two independent members of the company's Board of Directors to review the company's books and records since 1970 in order to determine what monies were used for purposes other than those shown on the company's books and records. A report will then be prepared and filed with the Commission as an exhibit to a current Form 8-K. The company's Board of Directors will then review the report and implement the findings of said report. If the Commission is not satisfied with the actions of the Board of Directors it reserves the right to seek such further relief as may be necessary or appropriate. Defendant George M. Steinbrenner III further agrees that if the Board of Directors determines that he should be required to reimburse the company for funds expended for political or any other unauthorized corporate purposes, as well as expenses incurred by the company by virtue of the Review Committee's investigation, Steinbrenner shall pay to the company all such amounts. Again if the Commission is not satisfied with the findings of the Board of Directors of the company, the Commission has the right to seek such relief as may be necessary or appropriate. ${ }^{38}$

AmShip's Review Committee used outside counsel to conduct the required internal investigation and to prepare the report filed with the Commission. A number of domestic political campaign contribution cases followed; almost all settled with consent decrees requiring an internal investigation. ${ }^{39}$

These domestic Watergate cases quickly led the SEC Enforcement Program into the era of sensitive and questionable foreign payments cases and eventually to an ongoing management fraud program. Ted Levine and Ed Herlihy in their important law review article in 1976 characterized the scope of the problem the SEC had found within corporate America:

37. See SEC v. American Ship Building (George M. Steinbrenner III), SEC Lit. Release No. 6534 (D.D.C. Oct. 4 , 1974) at 5 SEC Docket No. 8 at 242 (Oct. 16, 1974) (complaint alleged the making of domestic political contributions and other payments in excess of $\$ 120,000$ listed in company books and records as payments to employees).

38. Id.

39. See, e.g., SEC v. Waste Management, Inc., SEC Lit. Release No. 7333 (D.D.C. Mar. 29, 1976) at 9 SEC Docket No. 6 at 362 (Apr. 13, 1976) [hereinafter cited as Waste Management Case]; SEC v. Braniff Airways, Inc., SEC Lit. Release No. 7327 (D.D.C. Mar. 24, 1976) at 9 SEC Docket No. 5 at 292 (Apr. 6, 1976) [hereinafter cited as Braniff Airways Casel; Missouri Pub. Serv. Co., SEC Lit. Release No. 7299 (W.D. Mo. Mar. 4, 1976) at 9 SEC Docket No. 2 at 114 (Mar. 16, 1976) [hereinafter cited as Missouri Public Service Case]; SEC v. Ashland Oil, Inc., SEC Lit. Release No. 6890 (D.D.C. May 14, 1975) at 7 SEC Docket No. 1 at 362 (June 4, 1975) [hereinafter cited as Ashland Oil Case]; SEC v. Northrop Corp., SEC Lit. Release No. 6839 (D.D.C. Apr. 16, 1975) at 6 SEC Docket No. 16 at 410 (Apr. 29, 1975) SEC Lit. Release No. 6842 (D.D.C. Apr. 16, 1975) at 6 SEC Docket No. 16 at 419 (Apr. 29, 1975) [hereinafter cited as Northrop Case]; SEC v. Sanitas Serv. Co., SEC Lit. Release No. 6829 (D.D.C. Apr. 11, 1975) at 6 SEC Docket No. 16 at 107 (Apr. 29, 1975), SEC Lit. Release No. 6906 (D.D.C. May 29, 1975) at 7 SEC Docket No. 2 at 92 (June 10, 1975), SEC Lit. Release No. 6918 (D.D.C. June 4, 1975) at 7 SEC Docket No. 3 at I33 (June 17, 1975), SEC Lit. Rel. No. 6952 (June 30, 1975) at 7 SEC Docket No. 7 at 367 (July 15, 1975), SEC Lit. Release No. 7002 (D.D.C. July 24, 1975) at 7 SEC Docket No. 10 at 451 (Aug. 5, 1975), SEC Lit. Release No. 7184 (D.D.C. Nov. 28, 1975) at 8 SEC Docket No. 9 at 681 (Dec. 16, 1975), SEC Lit. Release No. 7422 (D.D.C. 1976) [hereinafter cited as Sanitas Casel; SEC v. Gulf Oil Corp., SEC Lit. Release No. 6780 (D.D.C. Mar. 11, 1975) at 6 SEC Docket No. 11 at 465 (Mar. 25, 1975) (hereinafter cited as Gulf Oil Case]; SEC v. Phillips Petroleum Co., SEC Lit. Release No. 6770 (D.D.C. Mar. 7, 1975) at 6 SEC Docket No. 6 at 419 (Mar. 19, 1975) [hereinafter cited as Phillips Petroleum Case); SEC v. Minnesota Mining \& Mfg. Co., SEC Lit. Release No. 6711 (D. Minn. Jan. 31, 1975) at 6 SEC Docket No. 6 at 242 (Feb. 18, 1975) (hereinafter cited as $3 \mathrm{M}$ Case]. 
Throughout much of history, corruption has been no stranger to money dealings between businessmen, politicians, and others. The trail of Watergate, however, has led to revelations of foreign and domestic bribes, kickbacks, political payoffs, and other questionable financial transactions involving U.S. and foreign corporations to an unprecedented extent and degree. These transactions have been facilitated by elaborate methods of concealment, including the falsification of records and the structuring of fictitious transactions, which are generally lumped under the rubric "management fraud."

The complexity and variety of the cases involving management fraud have perplexed observers. On a daily basis, new revelations of corporate misconduct, at home and abroad, are made. Although there is no distinct model or prototype, several factors typically are present, including the involvement of corporate management, the falsification of corporate books and records, the accumulation of secret pools of corporate funds or the diversion of funds from the corporate entity, and the illegality of the conduct involved. $^{40}$

The SEC's May 1976 Report to the Proxmire Committee of the United States Senate ${ }^{41}$ described the Commission's early efforts in the foreign payments enforcement arena, ${ }^{42}$ encompassing enforcement actions against such major corporations as Ashland Oil, ${ }^{43}$ Gulf Oil, ${ }^{44}$ Phillips Petroleum, ${ }^{45}$ Northrop, ${ }^{46}$ Braniff Airways, ${ }^{47}$ General Tire \& Rubber, ${ }^{48}$ Lockheed, ${ }^{49}$ and United Brands. ${ }^{50}$ By the time the Foreign

40. Herlihy \& Levine, Corporate Crisis: The Overseas Payment Problem, 8 LAW \& POL'Y IN INT'L Bus. 547, $547-48$ (1976) (footnotes omitted).

41. Report of the Securities and Exchange Commission on Questionable and Illegal Corporate Payments and Practices Senate Comm. on Banking, Housing and Urban Affairs, 94th Cong., 2d Sess. (1976) [hereinafter cited as Proxmire Committee SEC Payments Report].

42. Professor John C. Coffee observed:

Improper payments stories first began to trickle out from the swamp of Watergate when the Special Prosecutor's Office discovered that a sizable number of American corporations had made illegal political contributions during the 1972 presidential campaign. This freshet quickly swelled to a steady stream with the subsequent investigation initiated by the SEC to determine whether the absence of disclosure surrounding these payments had violated the federal securities laws. The floodstage was reached, however, only after the revelation of an unrelated and unsuspected scandal: "Bananagate." The dramatic exposure of United Brands misconduct occurred after the suicide of its prominent chief executive officer, Eli Black, whose death followed the commencement of an SEC investigation into a \$1.25 million payment, authorized by Black, to the President of Honduras, apparently to avoid the imposition of a confiscatory export duty on bananas. "Bananagate" shifted the focus of both SEC and popular attention from illegal domestic political contributions to the broader issues arising out of foreign and commercial bribery. It thus set the stage for the unfolding of the incredible saga of Lockheed Corporation and its worldwide efforts to bribe senior ministers of friendly foreign governments. Other notable instances of such payments, such as those of Gulf in South Korea, Exxon in Italy, and Northrop and Grumman in the Middle East, have been described in detail elsewhere, and in the aggregate suggest a level of corporate hubris and unchecked ambition reminiscent of Commodore Vanderbilt and the Nineteenth Century robber barons.

Coffee, Beyond the Shut-Eyed Sentry: Toward a Theoretical View of Corporate Misconduct and an Effective Legal Response, 63 VA. L. Rev. 1099, I115-16 (1977).

43. Ashland Oil Case, supra note 39.

44. Gulf Oil Case, supra note 39.

45. Phillips Petroleum Case, supra note 39.

46. Northrop Case, supra note 39.

47. Braniff Airways Case, supra note 39.

48. SEC v. General Tire \& Rubber Co., SEC Lit. Release No. 7386 (D.D.C. May 10, 1976) at 9 SEC Docket No. 12 at 664 (May 25, 1976) [hereinafter cited as General Tire Case].

49. SEC v. Lockheed Aircraft Corp., SEC Lit. Release No. 7355 (D.D.C. Apr. 13, 1976) at 9 SEC Docket No. 8 at 445 (Apr. 27, 1976) [hereinafter cited as Lockheed Case].

50. SEC v. United Brands Co., SEC Lit. Release No. 6827 (D.D.C. Apr. 10, 1975) at 6 SEC Docket No. 15 at 635 (Apr. 22, 1975), SEC Lit. Release No. 7251 (D.D.C. Jan. 27, 1976) at 8 SEC Docket No. 17 at 1177 (Feb. 10, 1976) [hereinafter cited as United Brands Case]. 
Corrupt Practices Act ${ }^{51}$ became effective in December $1977,{ }^{52}$ or shortly thereafter, the SEC had sued a potpourri of major American companies in questionable or illegal payments cases, including Boeing, ${ }^{53}$ International Telephone \& Telegraph, ${ }^{54}$ General Refractories, ${ }^{55}$ Grumman, ${ }^{56}$ Page Airways, ${ }^{57}$ Firestone Tire \& Rubber, ${ }^{58}$ General Telephone \& Electronics, ${ }^{59}$ Textron, ${ }^{60}$ and International Systems and Controls. ${ }^{61}$ Special counsel "internal investigation" was standard operating procedure in virtually every one of the consent settlements. Moreover, this device was a routine method employed in most of the commercial bribery, kickback, perks, and other management fraud cases brought during the balance of the $1970 \mathrm{~s}^{62}$

51. Foreign Corrupt Practices Act of 1977, 15 U.S.C. $\$ \S 78 \mathrm{~m}(b)(2), 78 \mathrm{~m}(b)(3), 78 d d-1,78 d d-2$ (1982).

52. See, e.g., Notification of Enactment of Foreign Corrupt Practices Act of 1977, SEC Act Release No. 34-14,478 [Accounting Series Releases Transfer Binder] Fed. SEC. L. ReP. (CCH) 1 72,264 (1978); A. Levenson, A. Mathews, \& H. Pitt, Foreign Corrupt Practices and Internal Accounting Controls (1980); A. Levensen, A. Mathews, \& H. Pitt, The Foreign Corrupt Practices Act of 1977. Do You Know This Act Governs Domestic Business ACTIVITIES? (1978).

53. SEC v. Boeing Co., SEC Lit. Release No. 8482 (D.D.C. July 28, 1978) at 15 SEC Docket No. 8 at 535 (Aug. 15, 1978) [hereinafter cited as Boeing Case].

54. SEC v. Intemational Tel. \& Tel. Corp., SEC Lit. Release No. 8407 (D.D.C. May 9, 1978) at 14 SEC Docket No. 16 at 1076 (May 23, 1978), SEC Lit. Release No. 8590 (Nov. 2, 1978) at 16 SEC Docket No. 1 at 75 (Nov. 15, 1978) [hereinafter cited as IT \& T Case]; see also SEC v. IT \& T, [1978 Transfer Binder] FED. SEC. L. REP. (CCH) If 96,586 (D.D.C. Nov. 2, 1978) (SEC complaint alleging IT \& T engaged in questionable payments to foreign governments), [1978 Transfer Binder] FED. SEC. L. REP. (CCH) \$ 96,452 (D.D.C. May 26, 1978) (order denying motion to seal SEC complaint and supporting documents).

55. SEC v. General Refractories Co., SEC Lit. Release No. 6898 (D.D.C. May 21, 1975) at 7 SEC Docket No. 1 at 53 (June 4, 1975), SEC Lit. Release No. 6919 (D.D.C. June 4, 1975) at 7 SEC Docket No. 3 at 133 (June 17, 1975), SEC Lit. Release No. 6928 (D.D.C. June 11, 1975) at 7 SEC Docket No. 4 at 176 (June 24, 1975), SEC Lit. Release No. 7069 (D.D.C. Sept. 4, 1975) at 7 SEC Docket No. 16 at 812 (Sept. 16, 1976), SEC Lit. Release No. 7098 (D.D.C. Sept. 24, 1975) at 7 SEC Docket No. 19 at 960 (Oct. 7, 1975), SEC Lit. Release No. 7544 (D.D.C. Sept. 1, 1976) at 10 SEC Docket No. 8 at 398 (Sept. 16, 1976) [hereinafter cited as General Refractories Case].

56. SEC v. Grumman Corp., SEC Lit. Release No. 8635 (D.D.C. Jan. 4, 1979) at 16 SEC Docket No. 10 at 644 (Jan. 16, 1979) [hereinafter cited as Grumman Case].

57. SEC v. Page Airways, Inc., SEC Lit. Release No. 8372 (D.D.C. 1978) at 14 SEC Docket No. 12 at 766 (Apr. 25, 1978) [hereinafter cited as Page Airways Case]; see also SEC v. Page Airways, Inc., [1979-1980 Transfer Binder] FED. SEC. L. REP. (CCH) I 97,341 (W.D.N.Y. Apr. 8, 1980); SEC v. Page Airways, Inc. [1978 Transfer Binder] FED. SEC. L. REP. (CCH) I 96,393 (D.D.C. Apr. 12, 1978).

58. SEC v. Firestone Tire \& Rubber Co., SEC Lit. Release No. 7443 (D.D.C. June 15, 1976) at 9 SEC Docket No. 17 at 920 (June 30, 1976) [hereinafter cited as Firestone Case].

59. SEC v. General Tel. \& Elecs. Corp., SEC Lit. Release No. 7760 (D.D.C. Jan. 31, 1977) at 11 SEC Docket No. 10 at 1662 (Feb. 21, 1977) [hereinafter cited as GT\&E Case].

60. SEC v. Textron, Inc., SEC Lit. Release No. 8993 (D.D.C. Jan. 31, 1980) at 9 SEC Docket No. 6 at 462 (Feb. 12, 1980) [hereinafter cited as Textron Case].

61. SEC v. Intemational Sys. \& Controls Corp., [1979-1980 Transfer Binder] FED. SEC. L. REP. (CCH) I 97,207 (D.D.C. Dec. 6, 1979); see also In re International Sys. \& Controls Corp. Sec. Litig., 693 F.2d 1235 (5th Cir. 1982), rev'g 91 F.R.D. 552 (S.D. Tex. 1981).

62. See, e.g., SEC v. Joseph Schlitz Brewing Co., SEC Lit. Release No. 8460 (E.D. Wis. July 7, 1978) at 15 SEC Docket No. 5 at 278 (July 25, 1975) [hereinafter cited as Schlitz Case]; SEC v. National Bank of Ga, SEC Lit. Release No. 8395 (N.D. Ga. May 3, 1978) at 14 SEC Docket No. 15 at 1029 (May 16, 1978) [hereinafter cited as National Bank of Georgia Case]; SEC v. Inflight Servs., Inc., SEC Lit. Release No. 8182 (S.D.N.Y. Nov. 3, 1977) at 13 SEC Docket No. 9 at 415 (Nov. 11, 1977) [hereinafter cited as Inflight Case]; SEC v. Sharon Steel Corp. (Posner), SEC Lit. Release No. 8119 (D.D.C. Sept. 20, 1977) at 13 SEC Docket No. 3 at 178 (Oct. 4, 1977) [hereinafter cited as Sharon Steel Case]; SEC v. Ormand Indus., Inc., SEC Lit. Release No. 7910 (D.D.C. May 10, 1977) at 12 SEC Docket No. 15 at 1984 (Mar. 22, 1977) [hereinafter cited as Ormand Case]; SEC v. Solon Automated Servs., Inc., SEC Lit. Release No. 7887 (D.D.C. Apr. 26, 1977) at 12 SEC Docket No. 2 at 271 (May 10, 1977) [hereinafter cited as Solon Case]; SEC v. Potter Instrument Co., SEC Lit. Release No. 7816 (D.D.C. Mar. 9, 1977) at 11 SEC Docket No. 15 at 1984 (Mar. 22, 1977) (hereinafter cited as Potter Case); SEC v. Canadian Javelin Ltd., SEC Lit. Release No. 7642 (D.D.C. Nov. 11, 1976) at 10 SEC Docket No. 18 at 984 (Nov. 18, 1976), SEC Lit. Release No. 7779 (D.D.C. Feb. 14, 1977) at 11 SEC Docket No. 12 at 1772 (Mar. 1, 1977), SEC Lit. Release No. 8751 (May 14, 1979) at 17 SEC Lit. Release No. 9 at 647 (May 29, 1979) [hereinafter cited as Canadian Javelin Case]; SEC v. Brad Ragan, Inc., SEC Lit. Release No. 7681 (W.D.N.C. Dec. 2, 1976) at 11 SEC Docket No. 1 at 1113 (Dec. 14, 1976) [hereinafter cited as Ragan Case]; SEC v. Seagram Co., Ltd., SEC 
V. Shift from SEC-Mandated, Court-Supervised, Independent, Special Investigations to Corporate-Controlled, Internal SelfInVESTIGATIONS: NORTHROP, GT\&E, GRUMMAN, THE SEC "VOLUNTARY Program," Diversified INDUSTRIES, AND THE FCPA

As the sensitive foreign payments cases mushroomed in the mid-1970s, the corporate defense bar awoke to the fact that proper corporate maneuvering in advance of, or in the midst of, an SEC enforcement investigation might lead to a less painful resolution of corporate payments problems than would be provided by a courtsupervised, SEC-monitored, consent-decree-restricted, independent special counsel investigation-usually reported in the public press. Corporations and their counsel began to ask why it would not be more prudent for a company to investigate itself privately without court supervision, SEC monitoring, or inflexible conditions imposed by a consent decree. By employing a self-investigation procedure, a company could use inside or outside counsel, not necessarily wholly independent, and at least not subject to prior approval of the SEC or the court. It was thought that by putting the corporate house in order in advance of an SEC enforcement attack or during the pendency of an SEC enforcement investigation, a company should be able to negotiate a milder settlement when the SEC did strike in a formal enforcement action and thus, be able to achieve an internal investigation less painful and perhaps more private than the special counsel investigations mandated by a rigid SEC consent decree.

Thus, another step in voluntary corporate accountability was taken. For example, in the Northrop foreign payments case, ${ }^{63}$ two of my partners, Howard Willens and Mike Klein, conducted the investigation ahead of the SEC, and their results were later rolled into an SEC consent decree. ${ }^{64}$ I suspect the conduct of the investigation

Lit. Release No. 8526 (E.D. Pa. Sept. 8, 1978) at 15 SEC Docket No. 14 at 1101 (Sept. 26, 1978) [hereinafter cited as Seagram Case]; SEC v. E.T. Barwick Indus., Inc., SEC Lit. Release No. 7520 (D.D.C. Aug. 10, 1976) at 10 SEC Docket No. 5 at 236 (Aug. 25, 1976), SEC Lit. Release No. 7640 (D.D.C. Nov. 8, 1976) at 10 SEC Docket No. 18 at 947 (Nov. 18, 1976), SEC Lit. Release No. 7767 (D.D.C. Feb. 1, 1977) at 11 SEC Docket No. 10 (Feb. 15, 1977) [hereinafter cited as Barwick Case]; SEC v. Emersons, Ltd., SEC Lit. Release No. 7392 (D.D.C. May 11, 1976) at 9 SEC Docket No. 12 at 667 (May 25, 1976) [hereinafter cited as Emersons Case]; Waste Management Case, supra note 39; Sanitas Case, supra note 39; In re Playboy Enters., SEC Act Release No. 34-17,059, [1980 Transfer Binder] FeD. SEC. L. REP. (CCH) II 82,635 (SEC Aug. 13, 1980); see also In re LTV Sec. Litig., 89 F.R.D. 595 (N.D. Tex. 1981); Canadian Javelin, Ltd. v. Lawler, Kent \& Eisenberg, 478 F. Supp. 448 (D.D.C. 1979); Osterneck v. E.T. Barwick Indus., 82 F.R.D. 81 (N.D. Ga. 1979); SEC v. Canadian Javelin, Lid., 451 F. Supp. 594 (D.D.C. 1978), vacated on procedural grounds, [1979 Transfer Binder] FeD. SEC. L. ReP. (CCH) I 96,742 (D.D.C. Dec. 13, 1978).

63. Northrop Case, supra note 39.

64. Northrop had commissioned outside counsel and outside auditors in March 1974 to conduct a massive intemal investigation on behalf of the company's independent outside directors as a result of the Watergate special prosecutor's office investigation of unlawful domestic political contributions by the company. In May 1974, Northrop's Board Chair, President, and Chief Executive Officer, Thomas V. Jones, and a former company vice president and director, James Allen, as well as the company itself, pled guilty to felony charges filed by the Watergate special prosecutor's office embracing illegal corporate domestic political campaign contributions. In May 1974 two private lawsuits-one class action and one derivative suit (Springer v. Jones, Civ. No. 74-1455 (C.D. Cal. 1974))-were brought involving the company and certain of its officers and directors. In November 1974, the independent outside directors received a special investigative report from the company's outside auditors. Based upon the auditors' report, the independent outside directors and outside special counsel conducted a worldwide investigation of Northrop's payments to foreign agents and consultants.

The worldwide investigation was part of an undertaking proffered in settlement of the private actions, which also required Northrop to appoint three new, independent members to its Board and to its Exccutive Committee supervising the investigation. A comparable undertaking was included in an SEC consent injunctive decree filed in April 1975. By that time Northrop--through its independent directors and outside counsel-virtually had completed the investigation. See Report to The Board of Directors of Northrop Corporation on the Special Investigation of the Executive Committee 1-2 (July 16, 1975). 
was much more tlexible, more private, and less painful thun the average foreign payments investigation conducted by an SEC-approved independent special counsel pursuant to a consent decree. And I am sure the language in the report of the invesligation was more generic than in those cases in which the special counsel was imposed and monitored from the start by both the SEC and the caut

In both the Grumman ${ }^{66}$ and the $G T \& E^{67}$ foreign payments cases, corporations followed the Northop example and chose outside counsel to conduct special investigations on behalf of the companies' respective audit committees prior to negotidting consent injunctions with the SEC. ${ }^{68}$ In both cases, the eventual consent decres merely required publicizing the reports of investigations already prepared voluntarily by the companies (although in Grumman one additional aspect of foreign activities was required to be further pursued by independent counsel since regular outside counsel conducting the principal investigation had counselled transactions in one particufar foreign country).

Corporate self-investigations not mandated by SEC consent decrees mushroomed as the SEC developed its "voluntary program" in 1975 and 1976. The Court of Appeals for the District of Columbia Circuit described the evolving practice as follows:

As early as 1974 the SEC was engaged in investigating the political "glosh fund" practices of some corporalions. Initially the SEC staff carried out its own investigations, but as the scope of the payments problen became apparent, extending to foreign as well as domestic payments, the SEC realized that in did not have the resources to investigate each case carefully. In several 1974 enforcemen actions, the SEC thus sought and obtained convent decrees in which corporate defendants agreed to appoint special committces of their boards of directors - composed entirely of directors unaffiliated with managementto carry out independent investigations of the defendants ' payment practices. These investigations were to be performed by outside counsel hired for that purpose and responsi-

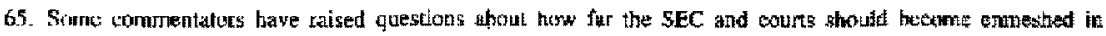

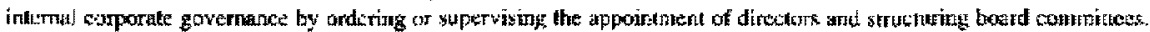

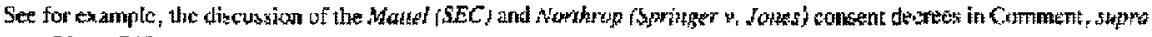
rut: $2 c_{*}$ : 740

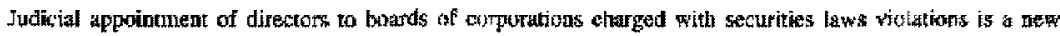
renedy that promises to grow in use and imporance. Sibse cours thus far have appinted dinetors only

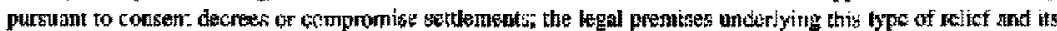

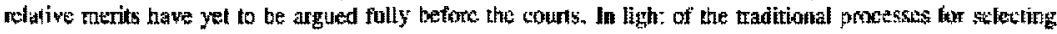

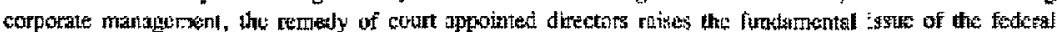

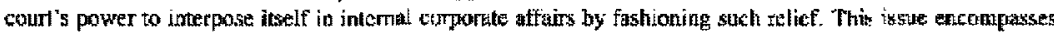

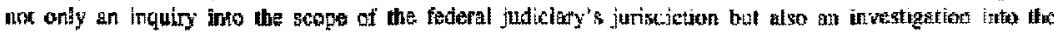

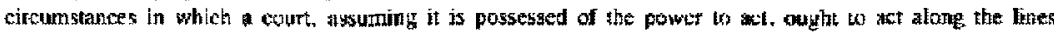

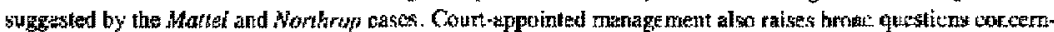

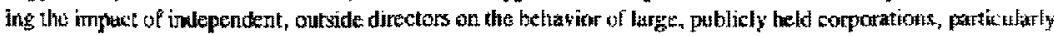
in relation to compliane with fetteral sedurities laws and the fidmiaty duthos of the indepentent directom 10 shburchoulers.

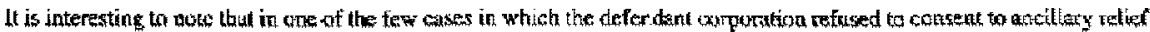

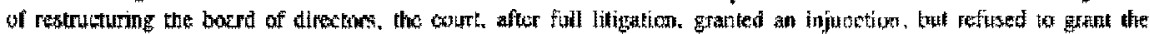

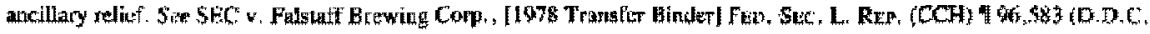

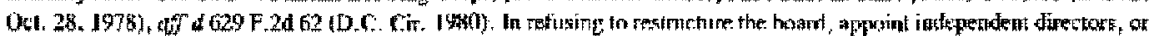

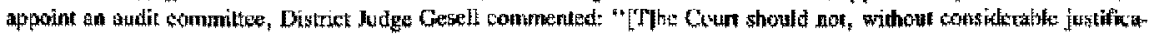

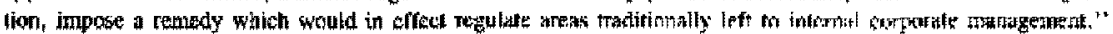

66. Grimman Cise, Nupre note 56

67. GTHE Canc, WMH Dolc S9.

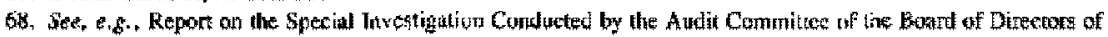

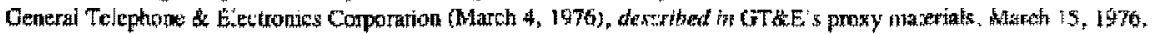


ble only to the special committee. The results of the investigation would be embodied in a report to the special committee which would also be shared with the SEC staff.

As the benefits of this method of investigation became apparent, the SEC began to encourage corporations to come forward voluntarily and perform the same type of independent investigation that the consent decrees had required. This effort to induce corporate self-investigation became known as the voluntary disclosure program. ${ }^{69}$

The court summarized the four major steps required by participation in the SEC's "voluntary program."

First, a corporation's board of directors should declare an end to all payments of doubtful legality and practices involving maintenance of inaccurate books and records. Second, the board should authorize a special committee composed primarily of independent directors to perform a thorough investigation of the corporation's practices, using independent counsel and auditors to prepare a report for the full board. Third, information on the commencement and progress of the investigation should be lodged with the SEC on its Form 8-K, and a copy of the final report should be filed with the SEC. Fourth, "[i]t must be understood that the staff of the Commission will have access to any information that is discovered or developed during the investigation." In return for such corporate cooperation, the SEC offered leniency for past abuses and a chance to avoid extended formal investigation and litigation. A report filed with the Senate Banking Committee in May 1976 provided details of roughly 60 corporations' compliance with the voluntary disclosure program. ${ }^{70}$

An example of a voluntary internal corporate investigation prior to SEC enforcement action is the Diversified Industries case. ${ }^{71}$ In 1974 and 1975, while engaged in a proxy fight encompassing two pieces of private litigation, it came to light that Diversified Industries may have engaged in commercial bribery by paying purchasing agents of customers from a slush fund maintained at the corporation. The proxy litigation was settled quickly and rather amicably. In the spring of 1975, prior to any SEC enforcement action, my law firm (Wilmer, Cutler \& Pickering) was retained by Diversified's Board of Directors to conduct an internal investigation of the commercial bribery allegations so the company could take appropriate steps to put its house in order. The investigation was completed, and a detailed report was submitted

69. In re Sealed Case, 676 F.2d 793, 800 (D.C. Cir. 1982) (footnote omitted).

70. Id. at 801 (footnote omitted). Professor Coffee commented:

Faced with a potentially enormous number of companies that had made such payments, and thus a severe burden on its enforcement resources, the Commission instead inaugurated in the summer of 1975 its Voluntary Disclosure Program. Under it, companies making voluntary "generic" disclosures of the aggregate amount and basic purposes of questionable payments (and agreeing to take other remedial steps) could escape both the constraints of a consent order injunction and the embarrassment of having to make public the delicate details of who got what, when, and why. The combined effect of the SEC's approach was a carrot-and-stick policy: the ability to make a "generic" disclosure rather than a full scale public confession constituted the "carrot," with the "stick" being the Enforcement Division's increasingly restrictive consent decree. Unquestionably, it worked. The SEC's initiation of this differentiated policy triggered a deluge of corporate disclosures involving several hundred companies.

Coffee, supra note 42, at 1117 (footnotes omitted).

71. See Diversified Indus., Inc. v. Meredith, 572 F.2d 596 (8th Cir. 1978) (en banc); see also SEC v. Diversified Indus., Inc., SEC Lit. Release No. 7650 (D.D.C. Nov. 15, 1976) at 10 SEC Docket No. 19 at 980 (Nov. 30, 1976), SEC Lit. Release No. 7722 (D.D.C. Dec. 30, 1976) at 11 SEC Docket No. 6 at 1400 (Jan. 18, 1977), SEC Lit. Release No. 8020 (D.D.C. July 7, 1977) at 12 SEC Docket No. 12 at 1443 (July 19, 1977), SEC Lit. Release No. 8640 (D.D.C. Jan. 11,1979 ) at 16 SEC Docket No. 11 at 753 (Jan. 23, 1979) [hereinafter cited as Diversified Case]. 
to the Board in December 1975. An SEC consent injunctive decree was entered in this matter almost a year later in late 1976. But the internal investigation was quite helpful to the company in negotiating the subsequent consent decree and alleviated the necessity of the SEC seeking broad, restrictive ancillary relief. ${ }^{72}$ Of course, the report of the investigation was provided to the SEC when the report was subpoenaed in the private SEC investigation.

The Diversified case has become well-known because in later private litigation, the issue arose whether the report had to be produced to Diversified's adversaries or whether it was shielded by the company's attorney-client and work-product privileges. A panel of the Eighth Circuit found that members of my firm were acting as investigators, not lawyers, and held that no privilege attached. ${ }^{73}$ On rehearing, however, the Eighth Circuit en banc held that we were lawyers performing legal services and sustained the privilege. ${ }^{74}$ The court en banc held that providing the report to the SEC in a private investigation pursuant to subpoena did not waive the attorney-client and work-product privileges for all purposes. The court, thus, denied the plaintiff's discovery of the documents on the grounds of attorney-client privilege. ${ }^{75}$ This "limited waiver" theory of the attorney-client privilege espoused in Diversified has been very controversial and has not been followed by other circuits. ${ }^{76}$ Nevertheless, the Diversified case highlights the importance of the language in the original retainer letter of special counsel and in the corporate resolution authorizing and directing counsel to conduct the investigation if the company expects to have any chance for any portion of a special investigation to be protected by the attorney-client and work-product privileges. ${ }^{77}$

The passage of the Foreign Corrupt Practices Act of $1977^{78}$ (FCPA) assured that internal corporate investigations would not be merely an interim phenomenon to get

72. Diversified Case, supra note 71.

73. Diversified Indus., Inc. v. Meredith, 572 F.2d 596, 603 (8th Cir. 1977).

74. Diversified Indus., Inc. v. Meredith, 572 F.2d 596, 610 (8th Cir. 1977) (en banc)

75. Id. at 611

76. See, e.g., United States v. El Paso Co., 682 F.2d 530, 538-42 (5th Cir. 1982) (corporation's blanket assertion of the privilege rejected); In re Sealed Case, 676 F.2d 793, 823-25 (D.C. Cir. 1982) (court rejected "limited waiver" doctrine but nonetheless ordered only limited disclosure); In re John Doe Corp., (Southland Corp.), 675 F.2d 482, 487-89 (2d Cir. 1982) (corporation waived privilege by using materials for purposes other than seeking legal advice); Permian Corp. v. United States, 665 F.2d 1214, 1220-22 (D.C. Cir. 1981) (narrow construction of privilege not overridden by need to accommodate SEC); compare In re LTV Sec. Litig., 89 F.R.D. 595 (N.D. Tex. 1981); see also Block \& Barton, Securities Litigation-Waiver of the Attorney-Client Privilege by Disclosure to the SEC, 10 SEC. REG. L.J. 170, 173-75 (1982); Gruenbaum \& Oppenheimer, Special Investigative Counsel: Conflicts and Roles, 33 RUTGERS L. REV. 865 (1981); Note, The Corporate Attorney-Client Privilege-A Compromise Solution: Diversified Indus., Inc. v. Meredith, 11 ConN. L. Rev. 94 (1978); Note, Limited Waiver of the Attorney-Client Privilege Upon Voluntary Disclosure to the SEC, 50 Fordham L. REv. 963 (1982); Note, Attorney-Client Privilege-Diversified Indus., Inc. v. Meredith: New Rules For Applying the Privilege When the Client Is A Corporation, 57 N.C.L. REv. 306 (1979); Comment, The Attorney-Client Privilege, the Self-Evaluative Report Privilege, and Diversified Industries, Inc. v. Meredith, 40 OHIO ST. L.J. 699 (1979); Note, Discovery of Internal Corporate Investigations, 32 STAN. L. REv. 1163 (1980); Comment, Stuffing the Rabbit Back Into the Hat: Limited Waiver of the Attorney-Client Privilege in an Administrative Agency Investigation, 130 U. PA. L. REv. 1198 (1982); see also Crisman \& Mathews, Limited Waiver of Attorney-Client Privilege and WorkProduct Doctrine in Internal Corporate Investigations: An Emerging Corporate "Self-Evaluative" Privilege, 21 AM. Crim. L. REv. 123 (1983).

77. See, e.g., Block \& Barton, Internal Corporate Investigations: Maintaining the Confidentiality of a Corporate Client's Communications with Investigative Counsel, 35 Bus. LAw. 5, 9-13 (1979); Fedders, Corporate Criminal Responsibility-Conducting an Internal Investigation, 3 CRIM. DEF. TECHS. (MB) ch. 62, at $\$ 62.02[2]$ (1983).

78. 15 U.S.C. $\$ \S 78 \mathrm{~m}(\mathrm{~b})(2), 78 \mathrm{~m}(\mathrm{~b})(3), 78 \mathrm{dd}-1,78 \mathrm{dd}-2$ (1982). 
corporate America through the SEC foreign payments program in the 1970s. The FCPA virtually guaranteed that internal corporate investigations would become an accepted part of American corporate life in the 1980s. Compliance with both the books and records and internal accounting controls provisions of Section $102^{79}$ and the anti-bribery provisions of Sections 103 and 104 of the FCPA has required hundreds of companies to utilize inside and outside accountants and auditors as well as inside and outside lawyers to conduct a wide variety of internal inquiries and investigations. In my view, no statute since the 1933 and 1934 Acts themselves has done more to effect corporate accountability by public companies than the FCPA. Also, corporate internal investigations of one kind or another have been a mainstay in achieving such corporate accountability.

An example of an internal corporate investigation minimizing the brunt of an eventual SEC enforcement action is the Playboy case. ${ }^{80}$ Playboy was a corporate perks case involving disclosure violations and violations of the books and records provisions of the FCPA. ${ }^{81}$ The corporation hired Al Sommer, then at my firm, and Steve Black (my partner who in 1983 directed the massive OPM bankruptcy trustee investigation) to conduct an internal corporate investigation on behalf of the Audit Committee. That self-investigation formed the predicate for settling the ultimate SEC enforcement action in an administrative, rather than civil injunctive, forum. ${ }^{82}$

If one ruminates on the quick review of fifteen years of SEC enforcement cases bearing upon internal corporate investigations (from VTR in 1965 to Playboy in 1980), an important developmental trend is highlighted: The internal corporate investigation began as an involuntary, SEC-imposed, court-supervised, public corporate enema to flush out corporate wrongdoing, usually governed by the ancillary relief provisions of an SEC civil injunctive consent decree. But the internal corporate investigation has evolved principally into a voluntary, self-controlled, private, more preventive corporate tool or vehicle, to assure proper corporate accountability and to attempt to avoid governmental enforcement action. At this point, let us reflect on why a corporation might choose to conduct an internal self-investigation and on what reasons exist that might lead a board of directors not to do so.

\section{Pros and Cons of an Internal Corporate Investigation}

\section{A. Factors in Favor}

First, to fulfill their statutory duty to manage the corporation in compliance with the law and for the benefit of the shareholders, directors need information. ${ }^{83}$ When a

79. See Goelzer, The Accounting Provisions of the Foreign Corrupt Practices Act-The Federalization of Corporate Recordkeeping and Internal Control, 5 J. CoRP. L. 1 (1979); Sommer, Internal Controls, 61 N.C.L. Rev. 505 (1983). 1980).

80. In re Playboy Enterprises Inc., [1980 Transfer Binder] FED. SEC. L. ReP. (CCH) If 82,635 (SEC Aug. 13.

81. 15 U.S.C. $\S \S 78 \mathrm{~m}(\mathrm{~b})(2)-(3), 78 \mathrm{dd}-1,78 \mathrm{dd}-2$ (1982).

82. In re Playboy Enterprises Inc., [1980 Transfer Binder] FED. SEC. L. REP. (CCH) I 82,635 at 83,421-22 (SEC Aug. 13, 1980).

83. In my experience, in great part due to the SEC's enforcement program in the 1970 s and the passage of the FCPA, the American business community is no longer plagued with yesteryear's problem of directors who don't direct. See also Sporkin, SEC Enforcement and the Corporate Boardroom, 61 N.C.L. REv. 455 (1982); Compare Douglas, Directors Who Don't Direct, 47 HaRv. L. Rev. 1305 (1934), with Small, The Evolving Role of the Director in Corporate Governance, 30 HAstings L. REv. 1353 (1979). 
company has multifaceted, worldwide operations, an internal investigation of certain trouble spots may be necessary to give both management and the board the necessary facts to determine whom to hire or fire, whom to promote or demote, what activities to divest or terminate and what modifications in business practice or activity to adopt or promote. Objective fact gathering often requires a noninvolved, disinterested fact gatherer. Since it appears that serious corporate misconduct typically occurs at lower levels of corporate management, often far below the board of directors and chief operating officer, high level executives need the benefit of internal investigations to react to and halt repeated misconduct. ${ }^{84}$ When more senior officers or employees are involved, independence of the inquiry is important for other reasons.

Second, an internal self-investigation is less painful than a government investigation. I have articulated over the years a set of fourteen "Rules of Thumb in Defending SEC Investigations." My Second Rule is:

Rule Two: Take control of the investigation-get the SEC out as quickly as possible.

a. Obviously, neither defense counsel nor his clients should engage in sharp tactics that smack of obstruction of justice, but within acceptable legal and ethical bounds, counsel should influence as much as possible the speed and scope of the investigation.

b. If necessary, have the client offer to investigate itself, or to have an independent special counsel conduct the investigation. The goal is to have a nonprosecutorial person, rather than a government enforcement agency, conduct whatever investigation is required. ${ }^{85}$

I can think of few cases in which a corporation's interests would be better served by enduring an adversarial governmental investigation directed by the legion of zealous enforcement lawyers Stanley Sporkin left behind at the SEC than by an internal self-investigation controlled by a committee of the corporation's own board of directors who-unlike government lawyers-can always be guided by a good faith exercise of the business judgment rule. I do concede, however, that the selfinvestigation may, in the short run, be more costly to the corporation in terms of legal fees than allowing the government to expend its resources in the investigation.

Third, compliance with the FCPA, particularly the books and records and internal accounting controls provisions of Section $102,{ }^{86}$ often will require an internal investigation by internal or external auditors or inside or outside counsel. ${ }^{87}$ Such

84. Professor Coffee, in his thought-provoking article, Beyond the Shut-Eyed Sentry: Toward A Theoretical View of Corporate Misconduct and an Effective Legal Response, 63 VA. L. REv. 1099 (1977), points out:

The SEC Payments Report suggests that corporate misconduct typically occurs at a much lower level within the corporate hierarchy than the senior executive suite. While in some cases the chief executive's office did direct the payments program (e.g., Gulf, Lockheed, United Brands, and Northrop), this pattem typifies only the minority of the cases. Of the first 89 cases studied by the SEC, top management had knowledge in only 40 cases (or $47 \%$ ) . . . . Similarly, a survey by the House Subcommittee on Oversight and Investigations found a $40 \%$ figure to characterize the 25 additional companies they investigated.

Coffee, supra note 46 at $1105 \mathrm{n} .11$; see also SubCOMM. ON OVERSIGHT AND INVESTTGATIONS OF THE House COMm. ON interstate and Foreign Commerce, 94th Cong., 2D Sess., Federal Regulation and Regulatory Reform 33-42, 51-53 (Subcomm. Print 1976); Senate Banking, Housing, and Urban affairs Cómm., 94th Cong., 2D Sess., Report of the Securities and Exchange Commission on Questionable and Illegal Corporate Payments AND Practices (Comm. Print 1976).

85. Mathews, The Role of Outside Counsel, 61 N.C.L. Rev. 483, 501 (1983) (emphasis added).

86. 15 U.S.C. $\& 78 \mathrm{~m}(b)(2)$ (1982).

87. See Comment, Corporate Self-Investigations Under the Foreign Corrupt Practices Act, 47 U. CHr. L. REv. 803 (1980). 
FCPA compliance inquiries are akin to antitrust compliance reviews that major corporations have been undertaking for at least the last twenty-five years since the electrical equipment industry's major price-fixing conspiracy in the late $1950 \mathrm{~s}^{88}$ Fourth, an internal self-investigation, if careful, thorough, and independent, may provide the board of directors with a solid basis for terminating or settling favorably derivative suits or class actions respecting the corporate problems investigated.

\section{B. Factors Against}

First, if confidentiality of the investigative work product cannot be maintained, the corporation by conducting an investigation merely may be building a case on behalf of the company's private or governmental adversaries, against the corporation's interest and the interests of its shareholders. Second, depending on what corporate skeletons are turned up, in light of the company's disclosure obligations under the federal securities laws, the company by investigating may be forced to make more negative disclosures than it otherwise would, thereby injuring its shareholders. In addition, the information uncovered, if publicized, may embarrass or physically endanger employees, agents, or other involved individuals and may cause existing or potential customers to shift their business to the company's competitors. ${ }^{89}$ Indeed, in the foreign payments cases, the publicity even toppled foreign governments. For example, former Japanese Prime Minister Tanaka likely became a "former" prime minister for conduct that just recently resulted in his criminal conviction for taking bribes in the Lockheed scandal. ${ }^{90}$

Third, major investigations by outside counsel and independent accounting firms are expensive. Consequently, in some cases in which I have represented smaller, financially insecure companies, I have advised them not to conduct an internal investigation and instead to let the SEC expend its budget in developing the facts. Fourth, particularly in domestic or foreign payments matters, the self-investigation may turn up facts requiring the company to amend its prior tax returns and may trigger an IRS investigation ${ }^{91}$ or other adverse regulatory action. ${ }^{92}$ Fifth, as demonstrated hereafter in this article in a discussion of the Southland Corporation case, ${ }^{93}$ the methodology and results of a private internal corporate investigation may subse-

88. See, e.g., Klingsberg, Internal Corporate Antirrust Investigations, in PRACTISING LAW INSTITUTE, supra note 2 , at 11; see also Whiting, Antitrust and the Corporate Executive, 47 VA. L. Rev. 929 (1961); Whiting, Antitrust and The Corporate Executive-Part II, 48 VA. L. Rev. 1 (1962). Cf. Pickholz, Confronting SEC Pressure: A Need for Legal Audits, Legal Times of Wash., Oct. 29, 1979, at 14-15.

89. See SEC v. Lockheed Aircraft Corp., 404 F. Supp. 651, 652 (D.D.C. 1975).

90. See Lehner \& Martin, Tanaka Trial's End Portends Turmoil: Impact on Japanese Politics Depends on the Public's Reaction, Wall St. J., Oct. 13, 1983, at 33 col. 2; Lehner, Tanaka Guilty of Taking Bribe From LockheedFormer Prime Minister Gets 4-Year Term and Is Fined \$2.2 Million by Japan Court, Wall St. J., Oct. 12, 1983, at 2, col. 2.

91. See, e.g., Upjohn Co. v. United States, 449 U.S. 383 (1981); see also United States v. Lipshy, 492 F. Supp. 35 (N.D. Tex. 1979) (IRS inquiry involving internal investigation of Zale Corporation); $c f$. SEC v. Zale Corp., 650 F.2d 718 (5th Cir. 1981).

92. For example, admissions made in the report of investigation in General Tire Case formed a basis for the FTC"s refusal to renew valuable broadcast licenses for General Tire's RKO television subsidiary. See RKO Gen., Inc. v. FCC, 670 F.2d 215 (D.C. Cir. 1981); General Tire Case, supra note 48; Report of the Special Review Committee of the Board of Directors of the General Tire \& Rubber Company (July 1, 1977).

93. See infra notes $135-99$ and accompanying text. 
quently become the subjects of vicious second-guessing in the public media. Thus, there are pros and cons to everything in corporate as well as human life. ${ }^{94}$

\section{Role of Internal Investigations in AfFecting Termination or Settlement of Derivative Suits: The GT\&E Example}

The SEC's sensitive foreign payments enforcement program, supplemented by the prior domestic political slush fund cases and the subsequent domestic commercial payments and corporate perks cases, sometimes collectively called the Commission's management fraud enforcement program, ${ }^{95}$ led to the development of another body of law that illuminated the significance of internal corporate investigations. I refer to the recently revitalized body of law respecting dismissal or settlement of stockholder derivative suits through application of the business judgment rule based upon the results of an independent corporate internal investigation. My friend Don Schwartz is much more expert than $I$ in discussing this developing field of law. ${ }^{96} \mathrm{I}$ shall just scratch the surface.

The illegal domestic political campaign contribution cases spawned a few wellknown stockholders derivative suits. ${ }^{97}$ The sensitive foreign payments cases accelerated the pace of derivative suit litigation as well as class actions for damages. ${ }^{98}$

94. See Morvillo, Voluntary Corporate In-House Investigations-Benefits and Piffalls, 36 Bus. LAw. 1871 (1981).

95. See Freeman, The Legality of the SEC's Management Fraud Program, 31 Bus. LAw. 1295 (1976); see also Sommer, The Disclosure of Management Fraud, 31 Bus. Law. 1283 (1976).

96. See Arsht, The Business Judgment Rule Revisited, 8 HofstRa L. Rev. 93 (1979); Block \& Barton, The Business Judgment Rule as Applied to Stockholder Proxy Derivative Suits Under the Securities Exchange Act, 8 SEC. REG. L.J. 99 (1980); Block \& Prussin, Termination of Derivative Suits Against Directors on Business Judgment Grounds: From Zapata to Aronson, 39 Bus. LAw. 1504 (1984); Coffee \& Schwartz, The Survival of the Derivative Suit: An Evaluation and a Proposal For Legislative Reform, 81 CoLum. L. Rev. 261 (1981); Dent, The Power of Directors to Terminate Shareholder Litigation: The Death of The Derivative Suit? 75 Nw. U.L. Rev. 96 (1980); Estes, Corporate Governance in the Courls, 4 HARv. Bus. REv. 50 (1980); Steinberg, The Use of Special Litigation Committees to Terminate Shareholder Derivative Suits, 35 U. MiAmI L. REv. I (1980); Veasay, New Insights Into Judicial Deference to Directors' Business Decisions: Should We Trust the Courts? 39 Bus. LAw. 1461 (1984); Comment, Special Litigation Committees-An Expanding and Potent Threat to Shareholder Derivative Suits, 2 CARDozo L. Rev. 169 (1980); Note, The Business Judgment Rule in Derivative Suits Against Directors, 65 CORNELL L. Rev. 600 (1980); Note, The Propriety of Judicial Deference to Corporate Boards of Directors, 96 HARv. L. Rev. 1894 (1983); Pitt \& Israel, Recent Cases Chart Use of Business Judgment Rule, Legal Times of Wash., Jan. 19, 1981 at 33; Buxbaum, "Maldonado" Cases Could Lock Shareholders' Door, Legal Times of Wash., Oct. 13, 1980, at 1; Hinsey, Maldonado (NY) v. Maldonado (Del.): Which Prevails? Legal Times of Wash., Aug. 4, 1980, at 1.

97. E.g., Cort v. Ash, 422 U.S. 66 (1975); cf. Miller v. American Tel. \& Tel. Corp., 507 F.2d 759 (3d Cir. 1974).

98. See, e.g.. Abbey v. Control Data Corp., 603 F.2d 724 (8th Cir. 1979); Cramer v. General Tel. \& Elecs. Corp., 582 F.2d 259 (3d Cir. 1978); Rosengarten v. Intemational Tel. \& Tel. Corp., 466 F. Supp. 817 (S.D.N.Y. 1979); $c f$. Burks v. Lasker, 441 U.S. 471 (1979) (disinterested directors permitted to terminate stockholders' derivative suit against other directors in certain circumstances); Levy v. Johnson, [1976-1977 Transfer Binder] FED. SEC. L. REP. (CCH) I 95,899 (S.D.N.Y. Feb. 15, 1977); Lewis v. Elam, [1977-1978 Transfer Binder] Fed. SEC. L. ReP. (CCH) \96,013 (S.D.N.Y. Apr. 5. 1977); Gall v. Exxon Corp., 418 F. Supp. 508 (S.D.N.Y. 1976); Meer v. United Brands Co., [1976-1977 Transfer Binder] FED. SEC. L. REP. (CCH) I 95,648 (S.D.N.Y. July 6, 1976); Auerbach v. Bennett (GT\&E), 47 N.Y.2d 619, 393 N.E.2d 994, 419 N.Y.S.2d 920 (1979); Parkoff v. General Tel. \& Elecs. Corp., 74 A.D.2d 762, 425 N.Y.S.2d 599 (1980), aff d 53 N.Y.2d 412, 425 N.E.2d 820, 442 N.Y.S.2d 432 (1981); Shaw v. Jamieson (Exxon), 55 A.D.2d 875, 390 N.Y.S.2d 111 (1977). See generally Gaines v. Haughton, 645 F.2d 761 (9th Cir. 1981); Johnson v. Trueblood, 629 F.2d 287 (3d Cir. 1980); Galef v. Alexander, 615 F.2d 51 (2d Cir. 1980) (dismissal of derivative suit under business judgment rule left to state law); Lewis v. Anderson, 615 F.2d 778 (9th Cir. 1979) (duly delegated committee exercising good faith business judgment, may terminate derivative action); Genzer v. Cunningham, $498 \mathrm{~F}$. Supp. 682 (E.D. Mich. 1980) (thorough and good faith investigation by special litigation committee sufficient to reach determination to terminate derivative suit); Maldonado v. Flynn (I), 485 F. Supp. 274 (S.D.N.Y. 1980), modified 671 F.2d 729 (2d Cir. 1982); Zapata Corp. v. Maldonado, 430 A.2d 779 (Del. 1981) (review of independent and good faith committee's decision to terminate derivative action left to business judgment of state court). 
The $G T \& E$ case is an example of how an internal corporate investigation can dilute the harshness of an expected SEC enforcement action and help dispose of problems arising in subsequent derivative and class action lawsuits. ${ }^{99}$ In the midst of the SEC sensitive foreign payments enforcement program in the mid-1970s, GT\&E became one of the multinational corporations whose foreign payments were designated for scrutiny by the SEC. GT\&E determined that it would be more advantageous to conduct and control as much of the investigation as possible than merely to submit to wholesale, harsh, governmental investigation. (Remember Rule Two of Rules of Thumb in Defending SEC Investigations. ${ }^{100}$ )

The SEC Enforcement staff, at the time strained beyond the limits of its available enforcement personnel in attempting to juggle over 100 multinational investigations, agreed to defer for a few months pursuit of its investigation of GT\&E in return for the company's promise to have its audit committee-utilizing outside counsel (my firm) not previously affiliated with the company-conduct a comprehensive internal corporate investigation of GT\&E's worldwide foreign payments activities. The price of this deferral of SEC investigation was GT\&E's commitment to provide the SEC access to all the underlying work product amassed in the internal investigation. Also, of course, GT\&E was required to pledge that its internal investigation would be done quickly and not be a dilatory attempt to forestall the SEC's enforcement inquiry.

Care was paramount at the start! Only by a very cautious structuring of the nature, scope, and procedures of the investigation would the company be assured of the maximum advantage of a very costly endeavor. The investigation was conducted on behalf of the audit committee of GT\&E's board of directors. To assure independence - a necessary ingredient if the results of the investigation were to be used in the future as a basis for the board of directors' bona fide business judgment in taking or declining to pursue any particular corporate action-the audit committee was restructured at the start to include only independent directors who had no prior role in any of the company's foreign payments activities. Only by assuring that the audit committee included no members of management or the board who may have approved—or failed to inquire about—questionable foreign payments, could the integrity of the investigation be preserved.

The eventual investigative report of the GT\&E audit committee disclosed a great deal of information about sensitive or questionable foreign payments in a number of countries, totalling millions of dollars. While the report was quite generic, it did address with specificity the roles of various members of management and to what degree, if any, they participated or authorized the foreign payments discussed. The payments report was publicly disclosed in GT\&E's SEC filings.

While the internal investigation was very useful, it was not a panacea. The SEC

99. Cramer v. General Tel. \& Elecs. Corp., 582 F.2d 259 (3d Cir. 1978); GT\&E Case, supra note 59; Parkoff v. General Tel. \& Elecs. Corp., 74 A.D.2d 762, 425 N.Y.S.2d 599 (1980), aff d 53 N.Y.2d 412, 425 N.E.2d 820, 442 N.Y.S.2d 432 (1981); see also Auerbach v. Bennett (GT\&E), 47 N.Y.2d 619, 393 N.E.2d 994, 419 N.Y.S.2d 920 (1979); Note, The Effect of Res Judicata on Shareholder Derivative Actions in New York: Parkoff v. General Telephone \& Electronics Corp., 47 ALB. L. Rev. 145 (1982).

100. See supra note 85 and accompanying text; see also Mathews, supra note 85 , at 484-86. 
did thereafter conduct a somewhat limited investigation-after the Enforcement staff had reviewed our investigative work product in detail-to assure that the audit committee investigation was reliable and complete and not a whitewash. The SEC also required GT\&E to consent to a civil injunctive decree in a subsequent enforcement action. ${ }^{101}$ However, the consent decree was less harsh than it would have been absent the internal investigation. Only the corporation-no individuals-were named as defendants. No further mandated investigation was to be monitored by the SEC, supervised by the court, and conducted by a special counsel whose choice would be influenced by the SEC and who would look to the SEC rather than the company for instructions. The cosmetics and language of the payments report were shaped by the company's own audit committee, not by the SEC Enforcement staff or an independent outside counsel directly influenced by the government enforcement agency.

After the SEC settlement, a shareholder brought a derivative suit against certain GT\&E directors and the company's outside auditors, alleging breach of their duties to the corporation in connection with the foreign payments activities. This is known as the Auerbach case. ${ }^{102}$ GT\&E immediately appointed a Special Litigation Committee (SLC) composed of three independent directors who had not been directors at the time the foreign payments were made, had no knowledge of or participation in the payments activities, and were not named as defendants in the derivative suit. ${ }^{103}$ The board of directors of GT\&E delegated to the SLC complete authority to determine what course of action the company should pursue respecting the derivative suit and other suits that had been or were subsequently filed.

The SLC immediately retained yet another independent counsel, former New York Court of Appeals Chief Judge Desmond, to advise it in determining how to deal with the derivative claim. ${ }^{104}$ The SLC and its eminent special counsel pursued an inquiry which included:

(1) The review of the prior audit committee investigation.

(2) A test of its completeness by interviewing the audit committee's investigative counsel.

(3) Review of relevant transcripts of testimony before the SEC and a study of documents collected during the prior investigation.

(4) Interviews with directors found to have participated in any way in the underlying transactions.

(5) Questionnaires completed by nonmanagement directors. ${ }^{105}$

Based upon the advice of its counsel and its own independent business judgment, the

101. GT\&E Case, supra note 59.

102. Auerbach v. Bennett (GT\&E), 47 N.Y.2d 619, 393 N.E.2d 994, 419 N.Y.S.2d 920 (1979).

103. In this respect, GT\&E was following the example of the SEC-and court-approved Litigation and Claims Committee of the Board in the Mattel case. See SEC v. Mattel, Inc., [1974 Transfer Binder] Fed. SEC. L. Rep. (CCH) I 94,754 (D.D.C. Aug. 8, 1974).

104. In several other cases, an eminent retired jurist has effectively been retained to serve as independent special counsel to advise a board of directors or a special boand committee on how to deal with a derivative suit. See, e.g., Abbey v. Control Data Corp., 603 F.2d 724 (8th Cir. 1979) (retired Chief Judge Fuld of New York Court of Appeals); Gall v. Exxon Corp., 418 F. Supp. 508 (S.D.N.Y. 1976) (retired Chief Justice Weintraub of New Jersey Supreme Court).

105. Block \& Jasinski, Involuntary Dismissal of Derivative Actions Under the Business Judgment Rule, in PractisING LAW INSTITUTE, supra note 2, at 175. 
SLC determined that continued prosecution of the Auerbach derivative suit and other related suits would not be in the best interests of the corporation. ${ }^{106}$

The dismissal of the Auerbach derivative action ultimately was sustained by the New York courts as a good faith exercise of independent business judgment by the SLC on behalf of GT\&E's full board of directors. ${ }^{107}$ The pivotal factor in sustaining the dismissal was the nature and quality of the underlying investigations-both the audit committee internal investigation and the independent review by the SLC. ${ }^{108}$

But the Auerbach suit was not the end of GT\&E's foreign payments problems. Two other GT\&E shareholders brought derivative suits. The Cramer suit was brought in federal court. ${ }^{109}$ The Parkoff suit, like Auerbach, was brought in the New York state courts. ${ }^{110} \mathrm{~A}$ third shareholder, Limmer, brought a class action for damages in federal court. ${ }^{111}$ And additional shareholders brought a second class action for damages in federal court, the Ross suit. ${ }^{112}$

Subsequent to the dismissal of the Auerbach suit by the trial court in New York, the federal court dismissed the Cramer suit based upon res judicata. ${ }^{113}$ The United States District Court for the Eastern District of Pennsylvania concluded that the New York state court judgment in Auerbach barred Cramer's claims even though the

106. See Auerbach v. Bennett (GT\&E), 47 N.Y.2d 619, 625-26, 393 N.E.2d 994, 997, 419 N.Y.S.2d 920, 923-24 (1979).

107. The emerging law of when, and under what circumstances, a board of directors can dismiss a derivative suit is outside the scope of this article. A convenient starting point is Burks v. Lasker, 441 U.S. 471 (1979). An excellent analysis of Burks and its progeny is provided in Coffee \& Schwartz, supra note 96. Professors Schwartz and Coffee describe the Auerbach (GT\&E) derivative litigation as follows:

Auerbach involved the familiar pattem of foreign bribes and kickbacks, paid in this instance by General Telephone \& Electronics Corporation to foreign govemmental customers. The decision not to sue was reached by a committee of three directors who had joined the board after the transactions in question. The trial court granted defendant's motion for summary judgment, based on this decision. See Auerbach v. Bennett (GT\&E), 64 A.D.2d 98, 103, 408 N.Y.S.2d 83, 85 (1978). The Appellate Division reversed, holding simply that summary judgment would require a fuller statement of the factors relied upon by the committee and the relative weight accorded them. Specifically, it asked the board to develop "the reasons for the payments, the advantages or disadvantages accruing to the corporation by reason of the transactions, the extent of the participation or profit by the respondent directors and the loss, if any, of public confidence in the corporation which might be incurred." Id. at 107, 408 N.Y.S.2d at 87-88. Reversing the Appellate Division, the New York Court of Appeals stated that such information was unnecessary because substantive judicial review of a board's decision was unavailable. Auerbach v. Bennett (GT\&E), 47 N.Y.2d 619, 633, 393 N.E.2d 994, 1002, 419 N.Y.S.2d 920, 928 (1979). Then, in a broad conclusory statement, it justified this rule: "To permit judicial probing of such issues would be to emasculate the business judgment doctrine as applied to the actions and determinations of the special litigation committee. Its substantive evaluation of the problems posed and its judgment in their resolution are beyond our reach." Id. at 634,393 N.E.2d at 1002, 419 N.Y.S.2d at 928.

Id. at 278 (footnotes omitted). Compare the Auerbach result with the result in the Second Circuit's opinion applying Connecticut law in Joy v. North, 692 F.2d 880 (2d Cir. 1982), cert. denied, 103 S. Ct. 1498 (1983). See also Hasan v. CleveTrust Realty Investors, [1983-1984 Transfer Binder] FED. SEC. L. REP. (CCH) \ 99,704 (6th Cir. Mar. 2, 1984); Holmstrom v. Coastal Indus., Inc., [1983-1984 Transfer Binder] FED. SEc. L. REP. (CCH) I 91,486 (N.D. Ohio May 30, 1984); In re Continental Ill. Sec. Litig., [1983-1984 Transfer Binder] FED. SEc. L. REP. (CCH) I 99,680 (N.D. II. May $6,1983)$.

108. Auerbach v. Bennett, 47 N.Y.2d 619, 634-36, 393 N.E.2d 994, 1003-04, 419 N.Y.2d 920, 929-30 (1979). 109. Cramer v. General Tel. \& Elecs. Corp., 443 F. Supp. 516 (E.D. Pa. 1977), aff d, 582 F.2d 259 (3d Cir. 1978). 110. Parkoff v. General Tel. \& Elecs. Corp., 53 N.Y.2d 412, 425 N.E.2d 820,442 N.Y.S.2d 432 (1981).

111. Limmer v. General Tel. \& Elecs. Corp., [1977-1978 Transfer Binder] Fed. SEc. L. ReP. (CCH) \96,111 (S.D.N.Y. Mar. 21, 1977).

112. Ross v. Warner, [1980 Transfer Binder] Fed. SEC. L. ReP. (CCH) I 97,735 (S.D.N.Y. Dec. 11, 1980).

113. Cramer v. General Tel. \& Elecs. Corp., 443 F. Supp. 516 (E.D. Pa. 1977), aff d, 582 F.2d 259 (3d Cir. 1978). 
Cramer complaint contained much broader allegations than the Auerbach complaint. ${ }^{114}$

Thereafter, the New York Court of Appeals sustained dismissal of the Parkoff complaint. ${ }^{115}$ Strange as it may seem, the court held that the Auerbach and Parkoff complaints encompassed separate and distinct events and underlying activities that did not constitute parts of a single transaction. In addition, Parkoff's attempt to intervene in the Auerbach litigation had been refused. Thus, it found that the $A u$ erbach judgment did not bar the Parkoff complaint. However, the court found the Cramer and Parkoff complaints to encompass identical claims. And Parkoff had not attempted to intervene in the Cramer suit. Therefore, the court held that the federal judgment dismissing Cramer barred the Parkoff suit on res judicata grounds, stating: "While in our view the disposition of the Auerbach litigation is not conclusive as to the Parkoff claims, for reasons which follow we reach a contrary result with respect to the disposition of the derivative action commenced by stockholder Cramer." 116 After analyzing the Cramer complaint, the court held:

Inasmuch as these [Cramer] matters are also the substance of plaintiff Parkoff's complaint, and because there has been no showing that he sought intervention and was excluded from participation in that action (as happened in the Auerbach litigation), we look to the disposition of the Cramer action and conclude that plaintiff is thereby barred from prosecuting the action now before us. ${ }^{117}$

The underpinning of the decision barring the Parkoff litigation was the court's findings that: (i) the shareholder's action being given res judicata effect-i.e., Cramerwas neither collusive nor fraudulent, (ii) the current plaintiff shareholder-i.e., Parkoff - was not frustrated in any attempt to join or intervene in the Cramer action which went to judgment, and (iii) both actions-i.e., Cramer and Parkoff-arose out of the same underlying transactions. ${ }^{118}$

The Limmer suit was eventually dismissed for failure to state a claim under the federal securities laws and a consequent lack of pendent subject matter jurisdiction over the state law claims asserted. ${ }^{119}$ The Ross suit was eventually dismissed on similar grounds. ${ }^{120}$

Needless to say, one of the principal underpinnings of the dismissals of all the class and derivative litigation in the $G T \& E$ cases was the initial underlying internal corporate investigation. When conducted with the requisite independence, the investigation was able to form a crucial basis for the exercise of independent business judgment by the appropriate board committee. ${ }^{121}$

114. Id. at 525; see also Note, The Effect of Res Judicata On Shareholder Derivative Actions in New York: Parkoff v. General Telephone \& Electronics Corp., 47 ALB. L. Rev. 145, 152-54 (1982).

115. Parkoff v. General Tel. \& Elecs. Corp., 53 N.Y.2d 412, 425 N.E.2d 820, 442 N.Y.S.2d 432 (1981).

116. Id., at 421, 425 N.E.2d 820, 824, 442 N.Y.S.2d 432, 436 (1981); see also Note, supra note 114, at 154-57.

117. Parkoff v. General Tel. \& Elecs. Corp., 53 N.Y.2d 412, 422, 425 N.E.2d 820, 825, 442 N.Y.S.2d 432, 437 (1981).

118. Id., at $415-22,425$ N.E.2d at $821-28,442$ N.Y.S.2d at $433-40$.

119. Limmer v. General Tel. \& Elecs. Corp., [1977-1978 Transfer Binder] Fed. Sec. L. Rep. (CCH) I 96,111 (S.D.N.Y. Mar. 21, 1977).

120. Ross v. Wamer, [1980 Transfer Binder] Fed. SEc. L. REP. (CCH) I 97,735 (S.D.N.Y. Dec. 11, 1980 ).

121. But see, Abbey v. Computer \& Communications Technology Corp., 457 A.2d 368 (Del. Ch. 1983) (corporation's board of directors may not appoint a disinterested special litigation committee to review the merits of a shareholder derivative suit and then move independently for dismissal of the suit before the committee has made its recommendations). 
We should not leave the derivative suit problems without taking note of the American Law Institute's ongoing Corporate Governance project. A substantial portion of Tentative Draft No. 1 of the American Law Institute's Restatement of Principles of Corporate Governance and Structure is devoted to the subject of dealing with derivative actions. ${ }^{122}$ Section 7.03 of Tentative Draft No. 1 governs "Termination of Derivative Action on the Basis of Board or Shareholder Action." 123 Section 7.03b states that if a derivative action names as a defendant any corporate fiduciary, good corporate practice should lead the board to take a number of steps prior to determining that the action is adverse to the corporation's interests, including (i) delegating the matter to a committee of independent directors; (ii) retaining an independent special counsel to advise the committee with respect to the issues raised in the derivative litigation; and (iii) having the committee conduct "an investigation into the disputed events and transactions commensurate with the gravity and plausibility of the claims," and prepare and distribute a written report of investigation to all interested parties. ${ }^{124}$ Thus, the American Law Institute's project would institutionalize the internal investigation mechanism. ${ }^{125}$

\section{Emerging Problems in Internal Corporate Investigations: CONFIDENTIALITY AND INTEGRITY Disclosure Issues}

Internal investigations conducted by special committees of the board or by special counsel pose a number of problems for both the corporation being investigated and for the special counsel conducting the investigation. Judge-made law respecting internal investigations is gradually developing, but to date the courts have not provided definitive or uniform guidance respecting many aspects of the conduct or consequences of a special investigation. Moreover, different types of investigations have spawned both different problems and different solutions to the same problem. For example, an investigation conducted by a special counsel pursuant to an SEC consent decree may be governed by different rules and principles than an internal investigation conducted for a board of directors in circumstances in which there is no pending SEC enforcement action or no existing consent decree. ${ }^{126}$

Gruenbaum and Oppenheimer have published a pertinent article discussing the conflicts and roles of special investigative counsel who operate pursuant to the charter of an SEC consent decree. ${ }^{127}$ Some commentators who have performed the role of

122. Restatement of Principles of Corporate Governance and Structure $\$ \S 7.01-.08$ (Tent. Draft No. 1 , 1982).

123. Id. $\$ 7.03$.

124. Id. $\$ \$ 7.03 \mathrm{~b}(\mathrm{i})-\mathrm{b}(\mathrm{iii})$.

125. See also id. $\S 7.03$ comment a.

126. Compare Diversified Indus., Inc. v. Meredith, 572 F.2d 596 (8th Cir. 1977) (Harper \& Row test applicable to determine extent of attomey-client privilege in investigation without SEC consent decree), and In re LTV Sec. Litig. 89 F.R.D. 595 (N.D. Tex. 1981) (corporation conducting independent investigation without an SEC order could assert attorney-client privilege), with SEC v. Canadian Javelin Ltd., 451 F. Supp. 594 (D.D.C. 1978) (no attomey-client privilege created in an investigation pursuant to an SEC consent decree), and Osterneck v. E.T. Barwick Indus., 82 F.R.D. 81 (N.D. Ga. 1979) (in an investigation pursuant to an SEC consent decree, attomeys who served as special counsel ordered to testify and produce documents).

127. Gruenbaum \& Oppenheimer, supra note 2. 
special counsel in a number of cases have outlined the vulnerability of special counsel. ${ }^{128}$ Block and Barton wrote a helpful article on procedures designed to maintain the confidentiality of the work product and investigative record generated and developed in an internal corporate investigation. ${ }^{129}$ However, emerging case law makes it almost impossible to guarantee privacy or confidentiality of the investigative record. ${ }^{130}$ Even in those cases in which confidentiality otherwise might be preserved through a combined assertion of attorney-client privilege and work-product doctrine supplemented by an argument for a corporate or business self-evaluative privilege, ${ }^{131}$ the federal securities laws nevertheless might require that many of the facts and

128. See, e.g., Fedders, Investigative Counsel's Vulnerability, in PRACTISING LAw INSTrTUTE, supra note 2, at 295; Queenan, Conducting Internal lnvestigations, in A. Levenson, A. MAThews \& H. Pitr, Foreign CoRrupt Practices AND INTERnal ACCOUNTING CONTROLS I8I (1980); see also Fedders, Corporate Criminal Responsibility-Conducting An Internal Investigation, 3 CRIM. DEF. TECHNiques (MB) ch. 62 (1983); Pitt, Special Investigative Counsel: The SEC's Independent Police Force or Corporate Representatives? in 1 Negotiating SEC CONSENT DeCREes, supra note 2, at 142.

129. Block \& Barton, Internal Corporate Investigations: Maintaining the Confidentiality of a Corporate Client's Communications with Investigative Counsel, 35 Bus. LAw. 5 (1979).

130. See Continental Ill. Sec. Litig., Fed. SEc. L. REP. (CCH) No. 1072 (May 16, 1984); In re Sealed Case (Tesoro Petroleum), 676 F.2d 793 (D.C. Cir. 1982) (documents prepared by corporations in-house counsel not protected by work product privilege); In re John Doe Corp. (Southland Corp.), 675 F.2d 482 (2d Cir. 1982) (limiting attorney-client privilege with regard to conversations with general counsel); see also United States v. El Paso Co., 682 F.2d 530 (5th Cir. 1982); Permian Corp. v. United States, 665 F.2d 1214 (D.C. Cir. 1981); Weil v. Investment/Indicators, Research \& Management, Inc., 647 F.2d 18 (9th Cir. 1981); In re Special Sept. 1978 Grand Jury (II) (Jenner \& Block), 640 F.2d 49 (7th Cir. 1980); Schnell v. Schnall (Saxon Indus.), 550 F. Supp. 650 (S.D.N.Y. 1982); Teachers Ins. \& Annuity Ass'n v. Shamrock Broadcasting Co., Inc., 521 F. Supp. 638 (S.D.N.Y. 1981); SEC v. Gulf \& Westem, 518 F. Supp. 675 (D.D.C. 1981); In re LTV Sec. Litig., 89 F.R.D. 595 (N.D. Tex. 1981); Bymes v. IDS Realty Trust, 85 F.R.D. 679 (S.D.N.Y. 1980); Block \& Barton, Securities Litigation-Waiver of the Attorney-Client Privilege by Disclosure to the SEC, 10 SEc. REg. L.J. 170 (1982); Note, Limited Waiver of the Attorney-Client Privilege Upon Voluntary Disclosure to the SEC, 50 FordHaM L. Rev. 963 (1982); Comment, Stuffing the Rabbit Back Into the Hat: Limited Waiver of the Attorney-Client Privilege in an Administrative Agency Investigation, 130 U. PA. L. REv. 1198 (1982); cf. In re Intemational Sys. \& Controls Corp. Sec. Litig., 693 F.2d 1235 (5th Cir. 1982) (sufficient anticipation of litigation triggers work product immunity); Upjohn v. United States, 449 U.S. 383 (1981) (answers to questionnaires posed by investigating committec covered by attomey-client privilege); Block \& Remz, After "Upjohn": The Uncertain Confidentiality of

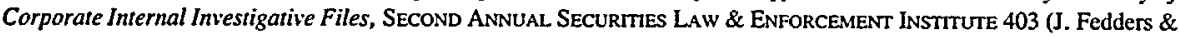
A. Mathews eds. 1983); Gergaez, Attorney-Corporate Client Privilege: Cases Applying Upjohn, Waiver, Crime Fraud Exception and Related Issues, 38 Bus. LAw, 1653 (1983); Klein, Attorney-Client Privilege and Work-Product Doctrine in the Corporate Context, in Practising Law Institute, Thirteenth Annual Institute on Securties Regulation 337 (hardcover ed. 1982); Mathews \& Borow, The Corporate Attorney-Client Privilege and Work-Product Doctrine, in The CoRporate Counsellor's DesK Book ch. 6, pp. 207-34 (Block, Hoddinott, \& Epstein eds. 1982); Pitt, Preserving Corporate Confidences: An Overview, in Practising Law Institute, ThirteEnth ANNual Institute on Securities Regulation 323 (hardcover ed. 1982); Miller, Recent Appellate Rulings Analyzing Scope of Attorney-Client Privilege, Nat'l L.J., Aug. 16, 1982, at 24.

13I. See, e.g., Diversified Indus., Inc. v. Meredith, 572 F.2d 596 (8th Cir. 1978) (en banc); In re LTV Sec. Litig., 89 F.R.D. 595 (N.D. Tex. 1981); Crisman \& Mathews, Limited Waiver of Corporate Attorney-Client and Work-Product Privileges: An Emerging Corporate Self-Evaluative Privilege, 21 AM. CRIM. L. REv. 123 (1983); Murphy, The SelfEvaluative Privilege, 7 J. CorP. L. 490 (1982); Note, The Privilege of Self-Critical Analysis, 96 Harv. L. Rev. 1083 (1983); Note, Discovery of Internal Corporate Investigations, 32 STAN. L. REv. 1163 (1980); Case Comment, Civil Procedure: Self-Evaluative Reports-A Qualified Privilege in Discovery? 57 MinN. L. REv. 807 (1973). See also Hall, Hospital Committee Proceedings and Reports: Their Legal Staulu, 1 AM. L.J. \& MED. 245 (1975) (privilege for certain internal hospital reports); Katz, Investigation and Conciliation of Employment Discrimination Charges Under Title VII: Employers' Rights in an Adversary Process, 28 Hastings L.J. 877 (1977); Note, A Balanced Approach to Affirmative Action Discovery in Title VII Suits, 32 Hastings L.J. 1013, 1024-31 (1981) ("public policy privilege"); Note, Government Access to Corporate Documents and Auditors' Workpapers: Shall We Include Auditors Among the Privileged Few? 2 J. Corp. L. 349 (1977); Comment, Corporate Self-Investigations Under The Foreign Corrupt Practices Act, 47 U. CHI. L. Rev. 803 (1980); Comment, Access to EEOC Files Concerning Private Employers, 46 U. CHI. L. Rev. 477 (1979); Comment, The Attorney-Client Privilege, the Self-Evaluative Report Privilege, and Diversified Indus., Inc. v. Meredith, 40 Oнıо ST. L.J. 699 (1979). Cf. United States v. Arthur Young \& Co., 677 F.2d 211 (2d Cir. 1982), aff'd in part and rev'd in part, 104 S. Ct. 1495 (1984). 
circumstances uncovered in the internal corporate investigation be publicly disclosed in SEC filings. ${ }^{132}$ Because of the amorphous, confusing integrity of management and related integrity theories of materiality, which the SEC sometimes advocates and to which courts sometimes refer, the disclosure issues attending the conduct of an internal corporate investigation can be the most sensitive, difficult issues with which counsel must deal. ${ }^{133}$

\section{Recent Illustrative Cases: Public Disclosure and Independence-Southland, Tesoro Petroleum, Citicorp, AND ASHLAND OIL}

Recent cases indicate that both investigating counsel and investigated corporate client may be particularly susceptible to criticism in the press respecting two crucial aspects of internal investigations, namely (1) whether the corporation made sufficient public disclosure at the conclusion of the internal investigation, and (2) whether counsel-and consequently the investigation itself-was sufficiently independent. The recent publicity in four cases-Southland Corporation, Tesoro Petroleum, Citicorp, and Ashland Oil-dramatizes the pitfalls faced by reputable counsel and reputable client corporations in dealing with internal investigations. ${ }^{134}$

\section{A. Southland Corporation: In re John Doe Corp. ${ }^{135}$}

In November 1976, Southland Corporation, parent of the 7-Eleven convenience store chain, was asked by the SEC to investigate whether there had been any

132. See, e.g., SEC v. Joseph Schlitz Brewing Co., 452 F. Supp. 824 (E.D. Wis. 1978) (disclosure of activities covered by internal investigation required on "integrity of management" theory of materiality); In re Carter and Johnson, SEC Act Release No. 34-17597, [1981 Transfer Binder] FED. SEC. L. REP. (CCH) I 82,847 (SEC Feb. 28, 1981); In re Keating, Muething \& Klekamp, SEC Act Release No. 34-15982, [1979 Transfer Binder] FED. SEC. L. REP. (CCH) I] 82,124 (SEC July 2, 1979) (counsel may have duty to assure disclosure is complete in client's SEC filings); Bauman, Rule IOb-5 and The Corporation's Affirmative Duty to Disclose. 67 Geo. L.J. 935 (1979); Bialkin, Legal and Practical Considerations for Disclosure of the Results of an Internal Corporate Investigation, in PRACTISING LAW INSTITUTE, supra note 2, at 129; Fogelson, The Reporting Company's Duties to Disclose and Correct in the Absence of Trading; Timely Disclosure of Negative Information, in Second Annual Securmties Law \& ENForcement Instirute 3 (J. Fedders \& A. Mathews eds. 1983); Mann, Disclosure of Results of Investigation, in Practising LAW INSTTIUTE, supra note 2, at 107; Sheffeg, Securities Law Responsibilities of Issuers to Respond to Rumors and Other Publicity: Reexamination of a Continuing Problem. 57 Notre Dame Law. 755 (1982).

133. See, e.g., Ferrara, Starr, \& Steinberg, Disclosure of Information Bearing on Management Integrity and Competency, 76 Nw. U.L. Rev. 555 (1981); Longstreth, SEC Disclosure Policy Regarding Management Integrity, 38 Bus. Law. 1413 (1983); Roiter, Illegal Corporate Practices and the Disclosure Requirements of the Federal Securities Laws, 50 Fordham L. Rev. 781 (1982); Speech by John M. Fedders on Failure to Disclose Illegal Conduct, [July-Dec.] 14 SEC. REG. \& L. REP. (BNA) 2057 (Nov. 26, 1982); Karmel, Speech, Qualitative and Differential Disclosure, reprinted in PRACTising LAw INstrTute, supra note 2, at 395.

134. See, e.g., Southland Corp. Investigations: Hearings Before the Subcomm. on Securities of the Senate Comm. on Banking, Housing, and Urban Affairs, 98th Cong., Ist Sess. (June 28, 1983); Should Law Firms Investigate Their Own Clients?. Bus. Wx., July 11, 1983 at 59 (Citicorp, Southland, and Ashland); Fedders Denies Wrongdoing in Southland Case, 83-125 SEC TODAY 1 (1983) (Statement of John Fedders) [hereinafter cited as Fedders Senate statement]; Noble, Business and the Law "Investigations By Lawyers, N.Y. Times, Sept. 6, 1983, at D-2, col. 1 (Citicorp, Southland, and Ashland); Vilkin, Fedders Doesn't Recall Key Events on Southland, Nat'l L.J., Aug. 29, 1983, at 5; Arieff, Ethics Reviews Still Deemed Useful for Business, Legal Times of Wash., July 25, 1983, at 4 (Citicorp. Southland, and Ashland); Arieff, SEC, Congress Question Counsel's Role in Review of Ashland Oil Payment, Legal Times of Wash., May 30, 1983, at 1; Thornton, Chief Enforcer at SEC Subject of Jury Probe, Wash. Post, May 30, 1983, at A-1, col. 6; Vilkin, Southland Case Raises Ethics Issue-Will Lawyers Testify?, Nat'l L.J., May 23, 1983, at 5; Southland Enters Plea of Innocent in Bribery Case, N.Y. L.J., May 12, 1983, at 1; Southland and 2 Charged in Bribe Case, N.Y. L.J., May 6, 1983, at 1.

135. See In re John Doe Corp. (Southland Corp.), 675 F.2d 482 (2d Cir. 1982). The press correctly identified the corporation as Southland Corporation a few weeks after issuance of the Second Circuit's opinion. 
"questionable practices to which [Southland] may have been a party since January 1, 1969." 136

After a preliminary legal review of the matters raised by the SEC, [Southland's] Board of Directors, acting on the recommendation of its Audit Committee, directed the Legal Department to conduct a confidential company-wide legal study and investigation of the Company's business practices. This investigation was the equivalent of the questionable payments inquiries conducted by over 500 other corporations during this time period. Its purpose was to provide a factual foundation which would enable the Legal Department to render legal advice about [Southland's] exposure to liability in potential litigation and about policies and internal controls to ensure compliance with applicable laws and regulations. [Southland] intended the investigation to be confidential. All documents and information generated were to be subject to the attomey-client and workproduct privileges. ${ }^{137}$

The internal investigation at Southland was conducted by Southland's in-house Legal Department, with the assistance of the company's regular Washington, D.C. outside counsel, Arnold \& Porter. Southland's General Counsel, Clark J. Matthews III, who directed the probe, was himself a former SEC enforcement lawyer and is a highly reputable, extremely talented professional. John Fedders, one of the partners at Arnold \& Porter, rendered assistance in the internal review. Fedders, who thereafter became Stanley Sporkin's successor as SEC Enforcement Chief, is an exceptionally able, trustworthy, top-notch lawyer. No one who has ever practiced law on either side of the table with John Fedders or Clark Matthews-and I have so practiced with each of them at various times over the past 21 years-can doubt the high sense of professional ethics of either. But hindsight, Monday morning quarterbacking in the press and in the courts in the last two years is picking apart their internal Southland investigation and testing both their honor and their will.

Fedders was a veteran in the conduct of internal investigations during the SEC's questionable payments era of the 1970s. He and his firm had conducted or advised about the conduct of numerous Southland-type internal investigations. ${ }^{138}$ Indeed, Fedders has published a chapter entitled Corporate Criminal ResponsibilityConducting An Internal Investigation in a criminal law treatise ${ }^{139}$ and has published a detailed outline entitled Investigative Counsel's Vulnerability in a Continuing Legal Education monograph. ${ }^{140}$ Both works provide excellent legal and practical guidance on structuring and conducting an internal corporate investigation. It appears that the methodology subsequently espoused publicly by Fedders in his writings had been used by Clark Matthews and his in-house legal staff-with Fedders' guidance and direction-in the Southland investigation. An independent accounting firm was specially retained to assist the inquiry. A detailed "privileged and confidential questionnaire" was distributed to 338 employees with management's direction that it was

136. Id. at 484 n.l.

137. $J$ d.

138. Fedders Senate Statement, supra note 134. For example, Fedders was one of the counsel in In re Grand Jury Subpoena Dated July 13, 1979 (Miller Brewing Co. and Phillip Morris, Inc.), 478 F. Supp. 368 (E.D. Wis. 1979).

139. Fedders, Corporate Criminal Responsibility-Conducting An Internal Investigation, 3 CRIM. DEF. TECHNIQUES (MB) ch. 62 (1983).

140. Fedders, Investigative Counsel's Vulnerability, in PRACTISING LAW INSTITUTE, supra note 2, at 295. 
Southland company policy to comply with all laws and regulations and that all employees were instructed to cooperate in the internal inquiry.

After analyzing employee responses to the questionnaires, [Southland's] lawyers interviewed selected employees. The lawyers advised these employees that the interviews were part of the Business Ethics Review and were privileged and confidential. ... [Southland's] lawyers compiled all the information they obtained in the investigation, organized it, analyzed the legal implications, and offered legal advice in a report entitled the Business Ethics Review. [Southland] regarded the report as privileged and confidential and took steps to preserve its confidentiality. The Legal Department presented its findings to the Board of Directors, which, among other actions, thereafter adopted a Code of Business Conduct to guide future operations of the Company. ${ }^{141}$

Twenty-five employees were interviewed before the questionnaire was devised and disseminated. The questionnaire sought information respecting, among other things, "any questionable payments to government officials, federal and state political contributions, commercial bribes, kickbacks, discounts and rebates, and off-book or inaccurately accounted for funds." ${ }^{142}$ After the affirmative responses to the questionnaires were analyzed and summarized, eighty-eight additional interviews were held. Outside counsel from Arnold \& Porter, including Fedders, participated in only three of the twenty-five initial interviews and in only one of the eighty-eight subsequent interviews. This was consistent with Southland's desire to hold down the costs of the internal investigation by having in-house counsel do as much of the investigative work as possible. ${ }^{143}$

Among a number of matters investigated was the payment of $\$ 96,500$ to a politically active Long Island lawyer (who served as a member of the New York City Council), Eugene Mastropieri, in connection with a number of sales tax cases brought by the New York State Tax Commission encompassing the correct sales tax liability when a 7-Eleven franchise is terminated. Eugene DeFalco, a Southland division manager, became concerned that the cases were not progressing rapidly enough and at the recommendation of a Long Island businessman, caused Southland to retain Mastropieri to assist Southland's regular Long Island counsel, Thomas Dougherty, in the state tax cases. ${ }^{144}$

Fedders described his awareness of the Mastropieri payment as follows:

Mastropieri then joined Dougherty as co-counsel in the sales tax cases. In July 1977, Mastropieri submitted the only bill he ever presented for his services. It was for $\$ 96,500$, and DeFalco sent it to Dallas, where it was paid by check.

Events that preceded the payment to Mastropieri were unusual and, frankly, suspicious. Prior to presentation of the legal bill, it had been suggested to Mr. Matthews that the payment be billed as an airplane lease. Mr. Matthews rejected the suggestion out of hand and insisted that Mastropieri would be paid only if he submitted a legal bill for services, which he ultimately did. I learned later in 1977 that Mr. Matthews became

141. In re John Doe Corp., 675 F.2d 482, 484 n.1 (2d Cir. 1982).

142. Fedders Senate Statement, supra note 134, at 11.

143. Id. at 9-12.

144. Id. at 13 . 
suspicious enough to inquire personally in June 1977 of Mr. Dougherty whether Mastropieri was providing professional assistance in this matter. Dougherty assured Matthews that Mastropieri was actually providing professional services. ${ }^{145}$

The internal investigation turned up some indications that at least two employees "harbored suspicions" that the Mastropieri fee "was inflated to include costs other than legal fees." 146 DeFalco's supervisor, Frank Kitchen, either at a sales meeting attended by several other Southland executives including its Board Chairman or from subsequent discussions with DeFalco, surmised "that a payment was going to be made to a state official for favorable treatment in a . . . tax liability case." "147 The other attendees at the sales meeting denied any discussion of any improper use of the fee. ${ }^{148}$

At the conclusion of the internal investigation, Southland's Legal Department prepared a seventy-one-page report for the Audit Committee. The report was edited and revised by Fedders as outside counsel. It discussed, among other items, political contributions, discounts paid, discounts received, and other activities, but never to Fedders' recollection did any draft refer to the Mastropieri fee. ${ }^{149}$ The Audit Committee considered the Legal Department report and had Fedders draft a six-page Audit Committee report to the Board of Directors. The Audit Committee report dated January 25, 1978, contained "A summary of the Legal Department's report, and includes a brief background of the investigation, conclusions and specific recommendations to Southland's Board made in light of the findings during the Business Ethics Review." 150 It did not, however, refer to the Mastropieri payment.

Mastropieri had been interviewed by telephone by Clark Matthews and "demonstrated familiarity with the substance of the sales tax cases." 151 Mastropieri claimed "his fee covered litigation costs through all appeals," and "indignantly rejected any suggestion that the fee was to be used for any illegal purpose."152

The Mastropieri fee and Clark Matthews' interview of Mastropieri were discussed orally with the Audit Committee. The Audit Committee itself questioned one Southland executive about the payment to Mastropieri. Fedders described the January 12, 1978 Audit Committee meeting as follows:

At the conclusion of a lengthy discussion of the Mastropieri matter, it was the view of all concerned that there was insubstantial evidence on which to base a conclusion of illegality and that the Legal Department would, therefore, not include the subject in its report. I believed at the time that this conclusion was reasonable. My partner, Bud Vieth, subsequently concurred in this judgment. ${ }^{153}$

145. Id. at 13-14 (footnote omitted).

146. Id. at 15-16.

147. Id. at 16; see also In re Kitchen, 706 F.2d 1266 (2d Cir. 1983) (Kitchen's civil contempt conviction for not answering grand jury questions reversed).

148. Fedders Senate Statement, supra note 134, at 16-17.

149. Id. at 18-20.

150. Id.

151. Id, at 21 .

152. Id.

153. Id. at 2l-22. 
In subsequent testimony to a Senate subcommittee, Fedders reviewed all the direct and circumstantial evidence about the Mastropieri payment then known to him and why it led him to believe that there was not sufficient evidence to support a conclusion that a bribe or other illegality had occurred. ${ }^{154}$

An additional factor considered by Fedders in deciding not to include a description of the Mastropieri payment in the written report was the risk of a defamation action. This risk is a consideration that every audit committee and special counsel must struggle with in determining how much to disclose publicly of the work product gathered in an internal investigation not mandated by a court order. ${ }^{155}$

It is clear that the Mastropieri matter was discussed orally with Southland's full Board of Directors, as well as with the Audit Committee, and that the Board concurred with the judgments of its counsel. ${ }^{156}$ Apart from this sensitive issue, inside and outside counsel, the Audit Committee, and the Board made two further judgment calls that arise in virtually every internal investigation: (1) what disclosure, if any, need be made publicly or to the SEC respecting the corporate activities embraced by and the results of the Business Ethics Review and (2) what documents, if any, should be retained or destroyed after the internal investigation was completed.

Since the SEC had not been promised access to the results or work product of the internal investigation, no informal disclosure was made to the SEC Enforcement staff. ${ }^{157}$ Applying the materiality test of the Northway case, ${ }^{158}$ a determination was made that the matters turned up in the internal inquiry were not material to Southland's shareholders or potential investors. Thus, no disclosure was made in any

\section{Id. at 23.}

155. Fedders stated:

In addition to the insubstantiality of evidence of illegality, a factor in my mind-which I believe I communicated to the Legal Department and to the Audit Committee-was that a conclusion that a bribe had been paid or planned, if expressed in a report of this kind, could be the basis of a defamation action. Before including in such a report any implication that a lawyer who had received a fee had intended to use it for a bribe to the New York State Tax Commission, more substantial evidence of wrongdoing than we had in January 1978 was required.

Fedders Senate Statement, supra note 134, at 23.

The danger of a defamation action is a real one. The writer and his partners participated in negotiating an SEC consent decree in one foreign payments case where the company was sued for libel and defamation by a person who fit the general description of a person not identified in the public report of the investigation, but described as possibly having been involved with questionable payments to foreign government officials. The writer and his partners are presently involved in a similar defamation action against the OPM Bankruptcy Trustee brought by a former OPM employeesalesman, and a leasing company he controlled, whose activities as they related to OPM were discussed in the OPM Trustee's Report of Investigation. See In re O.P.M. Leasing Servs., Inc., Report of the Trustee Concerning Fraud and Other Misconduct in the Management of the Affairs of the Debtor, Reorganization No. 81-B-10533 (BRL). (Bankr. S.D.N.Y. April 25, 1983); see also In re O.P.M. Leasing Servs., Inc., Debtor-George J. Prussin and Sha-Li Leasing Assocs., Inc. v. James P. Hasset, Individually and as Trustee of O.P.M., Adversary Proceeding No. 83-5799A, Reorganization No. 81-B-10533 (BRL) (Bankr. S.D.N.Y. 1983).

156. Fedders Senate Statement, supra note 134, at 23-26. Fedders pointed out:

Mr. Matthews described the Business Ethics Review, discussing the subjects covered by the Legal Department's report. Mr. Matthews then reported orally to the Board on the Mastropieri matter. He explained that while there were some suspicious circumstances, the Legal Department had been unable to determine that the fee was used for any illegal purpose. As a result, it had not been included in the report. His oral statement was Id. at 26. accepted by the Board, which agreed with the disposition of the matter.

157. Fedders Senate Statement, supra note 134, at 24.

158. See TSC Indus., Inc. v. Northway, 426 U.S. $438,450-51$ (1976). 
formal SEC filing, no press releases were issued, and no type of public disclosure was disseminated. ${ }^{159}$

Fedders has particular expertise on retention or destruction of documents. He has co-authored a law review article on the subject. ${ }^{160} \mathrm{He}$ advised Southland "to retain corporate documents secured during the investigation, as well as completed questionnaires and notes and memoranda of interviews." 161 However, he advised Southland to discard all drafts of the report of investigation:

Absent a legal duty to retain, it has been my policy to discard drafts of my work. I believed it to be a sound general policy which was applicable to this instance. A good lawyer lets the final version of his work speak for itself. Drafts only create ambiguities and raise doubts where none are intended. Consequently I advised the [Southland] Legal Department that at Arnold \& Porter we would discard all drafts, and I recommended Southland do the same. I insisted, however, that corporate documents be retained and suggested that documents relating to the Mastropieri matter be kept separately from those which related to what was discussed in the report. ${ }^{162}$

The issue of which documents should be retained and which ones discarded or destroyed at the completion of an internal investigation is, indeed, a difficult one. No specific hornbook rules apply. Fedders himself, in the conclusion to his Notre Dame Lawyer article, articulates the concerns very well:

Companies which adopt records management programs [i.e., document retentiondestruction programs] . . . confront difficult legal and ethical questions regarding, first, continuing $a d$ hoc search and destroy operations, and second, the timing of suspensions of routine document destruction programs in the face of "reasonably" or "clearly" foreseeable or pending investigations or proceedings. Beyond doubt, federal criminal statutes and the Code of Professional Responsibility are violated if management and counsel agree to destroy relevant documents after process requiring their production has been served. Furthermore, great risk of violation arises if management and counsel agree to destroy relevant documents in the course of voluntary cooperation with government authorities, or upon learning indirectly of relevant government inquiry. Many other actions by management and counsel, both intentional and inadvertent, give rise to the possibility of criminal and ethical sanctions.

For these reasons, what once was a simple business decision to destroy obsolete or seemingly inconsequential documents has become a senior management concern deserving serious and thoughtful attention. Lawyers must be prepared to assist business clients in responding to the continually enlarging sphere of difficulties surrounding the destruction of documents. The possible legal, practical and ethical consequences of document destruction are vast .....163

The Southland case demonstrates that when the destruction of drafts of an

159. Articulating the Northway "materiality" standard, Fedders commented "My judgment then was-as it is today-that there was no substantial likelihood that the disclosure of the information in the report would be viewed by reasonable shareholders or investors as having significantly altered the total mix of information then made available by Southland." Fedders Senate Statement, supra note 134, at 24.

160. Fedders \& Guttenplan, Document Retention and Destruction: Practical, Legal and Ethical Considerations, 56 Notre Dame LAW. 5 (1980); see also Borow \& Baskin, The Internal Corporate Investigation: Destruction of Documents and Routine Record Retention Programs, in PRACTISING LAw INSTITUTE, supra note 2, at 209.

161. Fedders Senate Statement, supra note 134, at 24-25.

162. Id. at 25 .

163. Fedders \& Gultenplan, supra note 160 , at 64. 
internal investigative report is coupled with selective disclosure of the final report to third parties who are in a position to provide advantage to the Company, disaster can follow. ${ }^{164}$

Unbeknownst to Fedders, after the Southland internal investigation, the company provided access to the confidential report of investigation to its underwriter's counsel and its outside auditors in connection with the public offering of seventy-five million dollars of Southland securities. ${ }^{165}$

The district court held that Southland's investigative report and materials were not privileged. Southland was held in contempt when it refused to produce the documents before a federal grand jury. ${ }^{166}$ The Second Circuit affirmed the contempt order. ${ }^{167}$ The circuit court observed that at an in camera hearing the government presented evidence "to support its claim that [Southland's] BER [Business Ethics Review] dated January 23, 1978, was in furtherance of a course of ongoing criminality," and that "a compelling need had been shown for the subpoenaed materials under the work-product doctrine." 168

Addressing the selective disclosure of the BER report to the outside auditors, the court pointed out testimony

that disclosure was in connection with the 1977 audit and was necessary to verify representations by [Southland's] management that no specific disclosures pertaining to matters in the BER were required in the 1977 financial statements. Had the accounting firm not been shown the BER, it would have issued only a qualified opinion on the 1977 statements. That would have been "disastrous" for [Southland] since the Securities and Exchange Commission . . . would not accept a qualified opinion were [Southland] to attempt to raise capital by a public offering of registered securities. ${ }^{169}$

The court went on to point out that in performance of "due diligence," counsel to the underwriter had inspected Southland's corporate minutes and had discovered that a business ethics review had been performed. ${ }^{170}$ Counsel insisted on having access to the BER to assure that the Southland prospectus and registration statement to be filed with the SEC were not false and misleading. Absent disclosure of the BER, there was a chance that the underwriter would refuse to go forward with the public offering. The court also pointed out that the outside auditors specifically questioned Southland's general counsel, Clark Matthews, "with specific questions about the $\$ 96,500$ paid to [Mastropieri].",171

164. See In re John Doe Corp., 675 F.2d 482 (2d Cir. 1982).

165. See Fedders Senate Statement, supra note 134, at 27:

I did not . . participate in any way in Southland's December 1978 underwritten public offering of $\$ 75,000,000$ in sinking fund debentures. Amold \& Porter has not, to my knowledge, ever represented Southland in any underwritten public securities offering, and it did not represent Southland in this one. Neither I nor any other Amold \& Porter attorney participated in any way, therefore, in a decision about whether to disclose to Touche Ross \& Co., Southland's independent public accountants, or to White \& Case, the underwriters' counsel in the December 1978 offering, either (1) the Business Ethics Review report, or (2) the Mastropieri matter. I leamed for the first time after April 1980, that the Business Ethics Review had been shown to Touche Ross \& Co. and to White \& Case in 1978.

166. See In re John Doe Corp., 675 F.2d 482 (2d Cir. 1982).

167. Id. at 483 .

168. Id. at 485 .

169. Id.

170. Id.

171. Id. 
Employees of the accounting firm conducting the continuous audit of [Southland] had been unable to substantiate the performance of any services by [Mastropieri]. Accountant brought this to General Counsel's attention, and inquired whether any portion of the fee had been used as a bribe .... No testimony was elicited at this time as to General Counsel's reply because of assertions of attorney-client privilege. ${ }^{172}$

Four of the five Southland employees who were subpoenaed to testify before the grand jury about the BER report, its drafts, and whether the Mastropieri matter had been disclosed in any drafts, declined to testify on Fifth Amendment grounds. ${ }^{173}$ However, the government produced a copy of a memorandum made by the auditor respecting his conversation with Southland's General Counsel (who declined to give grand jury testimony on Fifth Amendment grounds). The memorandum indicated that the Mastropieri matter had been disclosed in early drafts of the BER report, but was deleted after Clark Matthews' telephone interview of Mastropieri in which Mastropieri denied the bribe scheme and maintained he had rendered appropriate legal services. ${ }^{174}$

The Second Circuit concluded that Southland had waived its attorney-client privilege for two reasons: First, disclosure to the auditors in connection with the conduct of the audit constituted a waiver since it "evidences a corporate decision to use the materials for purposes other than seeking legal advice." Second, disclosure to counsel for the underwriter waived the privilege "so far as the payment to [Mastropieri] is concerned." 175

This is a more difficult conclusion to reach since the final BER made no mention of that payment. But General Counsel's statement to Accountant that mention had been made in earlier drafts and deleted after his investigation supports, we believe, the conclusion that silence was intended by [Southland] as an affirmance to all who read the BER of the propriety of the payment. Underwriter Counsel testified that bribes to public officials would have led him to ask [Southland] to include disclosure in its registration statement. Designation of the BER as a report on questionable practices and deletion of the discussion relating to [Mastropieri] in the final draft leads us to conclude that silence in this case was not a neutral statement. ${ }^{176}$

In articulating this rule, the Second Circuit relied on the Permian Corp. decision, ${ }^{177}$ where the D.C. Circuit Court rejected a "pick and choose" theory of attorney-client privilege.

172. Id.

173. Id. at 486 .

174. Id.

175. Id. at 488, relying upon In re Horowitz, 482 F.2d 72, 81 (2d Cir. 1973), cert. denied, 414 U.S. 867 (1973) (statements to accountants unrelated to the secking of legal advice are not privileged).

176. In re John Doe Corp., 675 F.2d 482, 489 (2d Cir. 1982).

177. Id.; see Permian Corp. v. United States, 665 F.2d 1214, 1221 (D.C. Cir. 1981). The court rejected Southland's argument that disclosure to underwriter's counsel was not voluntary because it was "coerced by the legal duty of due diligence and the millions of dollars riding on the public offering of registered securities." Id. The court explained:

A claim that a need for confidentiality must be respected in order to facilitate the seeking and rendering of informed legal advice is not consistent with selective disclosure when the claimant decides that the confidential materials can be put to other beneficial purposes. Federal securities laws put a price of disclosure upon access to interstate capital markets. Once materials are utilized in that disclosure, they become representations to third parties by the corporation. The fact that they were originally compiled by attomeys is irrelevant because they are serving a purpose other than the seeking and rendering of legal advice.

Id. at 489 (emphasis added.) 
The court in the Southland case also concluded that even had the attorney-client privilege not been waived, its assertion in that matter was inappropriate because a prima facie showing had been made that the BER and the assertion of privilege were part of a scheme of "ongoing criminality." 178 After reviewing an in camera submission made by the government, the court concluded "without difficulty" that there was "probable cause" to believe

1) the payment to [Mastropieri] was part of a criminal scheme to bribe public official(s);

2) a diligent investigation of that payment would not have provided a basis for deleting discussion of the payment to Lawyer from the final BER or for the reassurances given by General Counsel to Accountant . . ; 3) the final BER was used to conceal the criminal scheme from the underwriter for the public offering and the accounting firm certifying the 1977 financial statements; and 4) after the BER investigation, actions were taken in the name of the corporation to cover up the criminal schemes. ${ }^{179}$

Thus, the court applied the classic crime-fraud exception to the attorney-client privilege. ${ }^{180}$ At this juncture of the In re John Doe Corp. opinion, the court proffered some gratuitous advice that, I suggest, should be a cause for rumination by counsel and corporate client alike in structuring the methodology of an internal corporate investigation:

We recognize that corporate counsel coming upon evidence of criminality in communications protected under Upjohn are placed in an uncomfortable position. Their superiors or clients may well fear the commercial or even more serious personal consequences of disclosure. The lawyers' professional relationship to the corporation may extend well beyond aspects relating to criminal liability and leave them torn between a desire to see the firm prosper and their professional and legal obligations. In such cases, the wiser course may be to hire counsel with no other connection to the corporation to conduct investigations such as the BER. ${ }^{181}$

In my view, In re John Doe Corp. (Southland) is one of the two or three most important cases so far decided concerning what Al Sommer described as the "extralegal" institution of internal corporate investigations. ${ }^{182}$

The John Doe opinion handed down by the Second Circuit on March 23, 1982, did not end the Southland saga. Indeed, it had barely just begun. Throughout the summer and fall of 1982, the grand jury continued its investigation. ${ }^{183}$ In May 1983, the grand jury indicted Eugene Mastropieri, Southland Corporation, and Eugene DeFalco, a Southland division manager, for various charges of mail fraud, wire

178. In re John Doe Corp., 675 F.2d 482, 488 (2d Cir. 1982).

179. Id. at 491 . 1973).

180. Id., citing In re Doe, 551 F.2d 899 (2d Cir. 1977); see also United States v. Rosenstein, 474 F.2d 705 (2d Cir.

181. In re John Doe Corp., 675 F.2d 482, 491 (2d Cir. 1982) (citing Upjohn Co. v. United States, 449 U.S. 383 (1981)). The court emphasized that "[c]orporate counsel need not run to the FBI upon the first sign of criminality in an Upjohn protected communication" but cautioned that such communications are privileged only for the purpose of seeking and receiving legal advice. The investigation may not be used "to allay the concerns of third parties about possible criminal acts," to cover up a crime, or "to create the appearance of compliance with laws requiring disclosure." To do so vitiates the otherwise applicable privilege. In re John Doe Corp. (Southland), 675 F.2d 482, 491-92 (2d Cir. 1982).

182. The Southland court affirmed the district court's findings that the government "had made a sufficient showing of need to overcome the work-product doctrine." In re John Doe Corp. (Southland), 675 F.2d 482, 492 (2d Cir. 1982).

183. See Jury Studies Southland Payment, N.Y. Times, Aug. 3, 1982, at D-9, col. 3. 
fraud, and conspiracy to commit bribery of an unknown member of the New York State Tax Commission. ${ }^{184}$

The indictments charged that the supposed $\$ 96,500$ legal fee for Mastropieri was laundered through the Bank of Montreal in Toronto, Canada to establish a $\$ 20,000$ slush fund to finance the intended bribe. Mastropieri also allegedly paid a kickback for an undetermined amount to DeFalco without the knowledge of Southland's shareholders. The indictments charged that the labelling of the payment to Mastropieri as a "legal fee" was in fact a false entry in Southland's books and records. ${ }^{185}$ As part of the concealment of the conspiracy, the Mastropieri indictment also alleged that the Southland Business Ethics Review failed to disclose the continuing conspiracy to the company's audit committee, independent accountant auditors, outside tax counsel and the Securities and Exchange Commission. ${ }^{186}$

The Southland-DeFalco indictment alleged that Southland through its agents directed Frank Kitchen (a Southland officer) to disobey an order of a United States District Judge that he testify before the grand jury. ${ }^{187} \mathrm{Kitchen}$ was held in contempt, but the Second Circuit reversed his contempt conviction on procedural due process grounds. ${ }^{188}$ Southland and DeFalco originally pled innocent, ${ }^{189}$ but in September 1983, DeFalco changed his plea to guilty. ${ }^{190}$ Meanwhile, John Fedders and his former firm, Arnold \& Porter, suffered a merciless barrage of criticism and innuendo in the press-much of it unfair in my view-for the role they played in the internal investigation. ${ }^{191}$

One of the issues raised was whether it was appropriate for Arnold \& Porter to continue to defend Southland in the criminal case when present and former partners of Arnold \& Porter might be forced to testify at the eventual criminal trial respecting what knowledge they each did or did not have about particular aspects of the internal

184. See Southland And 2 Charged in Bribe Case, N.Y. L.J., May 6, 1983, at 1.

185. See id. Similar charges are contained in the Southland-DeFalco indictment.

186. Id. Mastropieri had been a member of the City Council of the City of New York until July 1980 and had been Chairman of the Committee on Economic and Industrial Development of the City Council. The indictments charged that Mastropieri did not perform, or even intend to perform, any substantial legal services and was retained to use his influence as a member of the City Council and to act as an intermediary in the payment of a bribe to a public official or officials of the Tax Commission. Newspaper reports of the indictments indicated that Mastropieri had resigned from the City Council in June 1980 "following his Federal indictment for aiding law clients to conceal nearly $\$ 500,000$ in income and evade more than $\$ 250,000$ in Federal income taxes," and that he was convicted and sentenced to jail in October 1980, and suspended from law practice in New York State in 1981. See Bribe Charges, N.Y. L.J., May 6, 1983, at 6.

187. Id.

188. See In re Kitchen, 706 F.2d 1266 (2d Cir. 1983); see also Vilkin, Southland Exec Wins Appeal-2d Circuit Reverses Contempt Citation, Nat'l L.J., May 9, 1983, at 9.

189. See Southland Enters Plea of Innocent in Bribery Case, N.Y. L.J., May 12, 1983, at 1.

190. See Vilkin, Southland Trial Postponed; Executive Enters Guilty Plea, Nat'l L.J., Sept. 26, 1983, at 3; Carley, New Grand Jury Probes Southland Corp. For Alleged Scheme To Bribe Tax Official, Wall St. J., Sept. 14, 1983, at 4, col. 2; Freid, Southland Official in Bribe Plea-Company Still Faces Charges, N.Y. Times, Sept. 14, 1983, at D-5, col. 1; Southland Executive Files Guily Plea on Eve of Trial, N.Y. L.J., Sept. 14, 1983, at 1.

191. See, e.g., Vilkin, Key Questions Likely to be Raised on Fedders' Role in Southland Probe, Nat'l L.J., June 13, 1983, at 3; Hudson, SEC's Fedders has Legal Bills Paid by Law Firm-Costs in Southland Corp. Case Met by Arnold \& Porter, His Previous Employer, Wall St. J., June 3, 1983, at 6, col. 3; Southland Probe Eyes SEC Chief of Enforcement, N.Y. Times, June 1, 1983, at A-1; Thomton, supra note 134; Vilkin, Southland Case Raises Ethics Issue-Will Lawyers Testify? Nat'] L.J., May 23, 1983, at 5. 
investigation. ${ }^{192}$ Another complicated issue for several months was Fedders' desire to testify before Congress about his role in the investigation and Southland's refusal to waive attorney-client privilege to allow him to testify. ${ }^{193}$

In his Senate testimony, in response to tough questioning by Senator D'Amato, Fedders stated that his role in the Southland investigation was "limited," even though he felt it was generally better to let independent counsel conduct such investigations. He explained his limited role as a product of Southland's desire to keep the costs of the investigation down through principal reliance on in-house counsel. ${ }^{194}$ Fedders also pointed out another pitfall of internal investigations-the lack of subpoena power-and rationalized that had Southland had the government's investigative powers, its internal investigation might have uncovered the bribery scheme. ${ }^{195}$

Amid all the publicity in the Southland case, ${ }^{196}$ it appears that the SEC itself has belatedly commenced a private investigation of the matter and that Fedders has given sworn testimony in that inquiry. ${ }^{197}$ And the grand jury is still continuing to investigate. Indeed, another Southland executive was indicted in November $1983 .{ }^{198}$ I suspect when all the criminal litigation in Southland is over, the cases will provide

192. See Vilkin, Southland Case Raises Ethics Issue-Will Lawyers Testify? Nat'l L.J., May 23, 1983, at 5; see also MOdel CODE OF Professional Responsibiltty DR 5-I02 (1980); Vilkin, Southland Trial Postponed; Executive Enters Guilty Plea, Nat'1 L.J., Sept. 26, 1983, at 3; Vilkin, Fee Was for Influence, Southland Aide Told FBI, Nat'l L.J., July 18 , 1983, at 4.

193. See Thornton, supra note 134. Representative Dingell had reportedly stated: "The Southland matter raises issues of character and integrity which may reflect on his fitness to hold his present office. Mr. Fedders has been taking positions on legal and policy matters, some of which may involve issues in the Southland case where he has a strong personal interest at stake." Id. Dingell's House Energy and Commerce Subcommittee was seeking to explore Fedders' role in private practice in the Southland matter and to explore in light of Fedders having become SEC Enforcement Chief why the SEC had taken no action in the case. In light of Representative Dingell's comments to the press, it is understandable that when Fedders was informed that he was a "subject" but not a "target" of a continuing grand jury inquiry and therefore was free to testify to attempt to clear his name (even though Southland had not waived its asserted privilege), Fedders testified before a Senate subcommittee chaired by Senator D'Amato rather than appearing before Representative Dingell. See Fedders' Senate Statement (June 28, 1983); Fedders Invites Hearing On His Role In Alleged Bribery Conspiracy Matter, 15 SEC. REG. \& L. REP. (BNA) 1019 (June 3, 1983); Fedders Denies Wrongdoing in Southland Case, 83-125 SEC TODAY 1 (1983) (reporting Fedders' testimony before Subcommittee on Securities of Senate Committee on Banking, Housing and Urban Affairs); Fedders Denies Prior Knowledge of Alleged Southland Conspiracy. 15 SEC. REG. \& L. REP. (BNA) 1259 (1983); Vilkin, Fedders Describes Role in Southland Investigation, Nat'l L.J., July 11, 1983, at 3 .

194. Fedders stressed that "[f]or a company to be cost conscious is not improper." 83-125 SEC Today 2 (1983).

195. See Fedders Denies Prior Knowledge of Alleged Southland Conspiracy, 15 SEC. REg. \& L. REP. (BNA) 1259-60 (1983): "Contending that any private investigation has limitations, Fedders argued that if Southland had the government's power to subpoena witnesses and to compel truthful testimony, 'further investigation might have uncovered additional relevant facts.' "'

196. See, e.g., The Complex Case of the U.S. v. Southland-To What Extent Are Companies Liable for Their Employees' Crimes, Business Week, Nov. 21, 1983, at 108.

197. See, e.g., Vilkin, Fedders Doesn't Recall Key Events on Southland, Nat'I L.J., Aug. 29, 1983, at 5.

198. See, e.g., Southland Executive Indicted; Grand Jury Probe Continuing, Nat'l L.J., Nov. 28, 1983, at 5 (indictment of Southland Senior Vice President S. Richmond Dole); A Second Top Official At Southland Indicted In Bribery Conspiracy, Wall St. J., Nov. 21, 1983 at 47, col. 3. 
further guidance for avoiding pitfalls in the conduct of internal corporate investigations. ${ }^{199}$

The tough disclosure issue faced by inside and outside counsel in the Southland case remind me that John Fedders-after he donned his SEC Enforcement helmetdid join with SEC Commissioner Bevis Longstreth in attempting to provide corporate America and the Bar with some guidance regarding when the SEC would take the position in a formal enforcement action that the federal securities laws require disclosure based upon an "integrity of management" or related "integrity of sales or earnings," "integrity of books and records," or "integrity of assets" rationale. ${ }^{200} \mathrm{In}$ his November 1982 ABA speech, Fedders offered five propositions for guidance as to SEC enforcement policy in the "management integrity" disclosure area. Let me quote a portion of his summary:

First, the Commission should begin enforcement actions where failure to disclose unlawful conduct violates traditional quantitative standards of materiality . . . . However, conduct that violates federal, state or foreign law, may be, but is not necessarily material ....

Second, the Commission should initiate enforcement actions where there is a failure to disclose self-dealing or conflict of interest transactions . . . .

Third, the Commission should commence enforcement actions where there is a failure to disclose information mandated by the disclosure requirements of the Commission's rules for proxy materials, periodic reports or registration statements-

199. There has been a great deal of activity in the Southland case since the submission of this article. The criminal trial was held in May 1984. John Fedders was called as a witness. Southland Corporation and Mastropieri were convicted by the jury, but the jury hung and a mistrial was declared regarding Southland officer $\mathbf{S}$. Richmond Dole. Thereafter, in August 1984, the grand jury retumed a new indictment against Mr. Dole and added an additional defendant-Southland's general counsel, Clark J. Matthews III. Messrs. Dole and Matthews are presently awaiting trial on the new indictment. Another Southland Official Charged, One Is Reindicted, Nat'l L.J., Aug. 13, 1984, at 1; Kohn, Third Official Implicated: Retrial For Bribe Conspiracy Set For Southland Executive, N.Y. L.J., Aug. 3, 1984, at 1; Freid, Southland Official Is Charged-Company Gets \$10,000 Fine, N.Y. Times, Aug. 3, 1984, at 33; Southland Corp. Fined; Kohn, Third Official Indicted In Probe Of Bribe Plan, Wall St. J., Aug. 3, 1984, at 1; Riley, The End Of The Line In Southland Probe? Nat'] L.J., June 25, 1984, at 1; Capeci, Was There A Company Conspiracy? Nat'l L.J., May 28, 1984, at 13.

200. See SEC Commissioner Longstreth, Remarks to Investors Responsibility Research Center in New York City (Oct. 18, 1982). An expanded version of these remarks was recently published as Longstreth, SEC Disclosure Policy Regarding Management Integrity, 38 Bus. LAW. 1413 (1983); see also KARMEL, Regulation by Prosecution ch. 7 (1982); A. Mathews, Management Integrity Theories of Materiality and SEC Disclosure Requirements in Materials, Univ. of Cal. 10th Annual Securities Regulation Institute (1983); Branch \& Rubright, Integrity of Management Disclosures Under the Federal Securities Laws, 37 Bus. Law. 1447 (1982); Ferrara, Star, \& Steinberg, supra note 133; Karmel Cites Trend Away From Economic Materiality As Disclosure Problem For Both SEC and Business, 526 SEC. REG. \& L. REP. (BNA) A-8 (1979); Roiter, Illegal Corporate Practices and the Disclosure Requirements of the Federal Securities Laws, 50 Fordham L. Rev. 781 (1982); Comment, Disclosure of Regulatory Violations Under the Federal Securities Laws: Establishing the Limits of Materiality, 30 AM. U.L. Rev. 225 (1981); Speech by John M. Fedders on Failure to Disclose Illegal Conduct. 14 SEC. REG. \& L. REP. (BNA) 2057 (Nov. 26, 1982) [hereinafter cited as Fedders Speech): R. Karmel (then SEC Commissioner), Qualitative and Differential Disclosure, speech at Financial Executives Institute International Conference, Atlanta, Georgia (Oct. 17, 1979). Compare Decker v. Massey-Ferguson, Ltd., 681 F.2d 111 (2d Cir. 1982); SEC v. Washington County Util. Dist., 676 F.2d 218 (6th Cir. 1982) (integrity of books violated by showing a paper profit); United States v. Stirling, 571 F.2d 708 (2d Cir. 1978) (integrity of sales and purchases of stock); SEC v. Joseph Schlitz Brewing Co., 452 F. Supp. 824 (E.D. Wis. 1978) (disclosure of hiring practices based on integrity of management); and SEC v. Kalvex, Inc., 425 F. Supp. 310 (S.D.N.Y. 1975) (integrity of management requires disclosure); with Abbey v. Control Data Corp., 603 F.2d 724 (8th Cir. 1979) (illegal foreign payments should not be dealt with under disclosure provisions); and SEC v. Chicago Helicopters Indus. Inc., No. 79-C-0469 (N.D. Ill. Jan. 18, 1980); Amalgamated Clothing v. J.P. Stephens \& Co., 475 F. Supp. 328 (S.D.N.Y. 1979), vacated as moot, 638 F.2d 7 (2d Cir. 1980) (per curiam) (integrity of management not implicated in failure to disclose plan to do illegal acts). 
particularly facts about director or senior officer conduct. By its enforcement efforts, the Commission must preserve the integrity of the line item disclosure requirements.

Fourth, the Commission should begin enforcement actions when untrue statements of material facts are made or statements made are misleading by the omission of material facts. Issuers must be held accountable for materially misleading statements in disclosure documents.

Fifth, absent the foregoing circumstances, the Commission generally should not utilize the antifraud provisions of the securities laws for law enforcement where there is a failure to disclose conduct which may be considered qualitatively material . . . . [T] here are no benchmarks of general application in the area of qualitative materiality. The Commission has not promulgated line item disclosure requirements relating to all illegal conduct, or, to the extent necessary, articulated a policy for law enforcement where information about such conduct has not been disclosed. Therefore, corporations do not have the procedural benefit of a rule specifying what type of unethical, antisocial or illegal conduct may be deemed to be material by the Commission. Significant uncertainties and potential liabilities exist. ${ }^{201}$

Unfortunately, statements of enforcement policy are not law. Courts may be influenced by Fedders' speech to apply a narrow view of materiality via the integrity theories. But they may also disregard his pronouncements.

\section{B. In re Sealed Case (Tesoro Petroleum) ${ }^{202}$ and In re Subpoenas Duces Tecum (Fulbright \& Jaworski and Vinson \& Elkins) ${ }^{203}$}

In April 1982, the District of Columbia Circuit issued an opinion in a foreign payment case styled In re Sealed Case ${ }^{204}$ The decision, like the Southland decision, is of importance in the development of the law surrounding internal corporate investigations. While the John Doe (Southland) opinion of the Second Circuit dealt primarily with attorney-client privilege aspects of internal investigations, the Sealed Case (Tesoro Petroleum) opinion of the D.C. Circuit wrestles principally with the attorney work-product doctrine respecting an internal investigation.

A federal grand jury in the District of Columbia was investigating Tesoro's foreign payments. When the grand jury subpoenaed the files of Tesoro's in-house general counsel relating to the company's internal payments investigation, the company and its agent (an in-house lawyer) refused to produce the files, claiming workproduct protection. The company's agent was held in contempt. On appeal, the D.C. Circuit held that six of the eight subpoenaed files might be subject to valid work-

201. Fedders Speech, supra note 200, at 1-2 (footnotes omitted) (emphasis added). For an article dealing with the related area of the SEC's development and refinement of disclosure standards generally through ad hoc administrative disciplinary proceedings, rather than by rulemaking, see Rowe, Disclosure Standards in SEC Proceedings, 16 REV. SEC. REG. 965 (1983).

202. In re Sealed Case (Tesoro Petroleum), 676 F.2d 793 (D.C. Cir. 1982).

203. In re Subpoenas Duces Tecum (Fulbright \& Jaworski and Vinson \& Elkins), [1983-1984 Transfer Binder] FED. SEC. L. REP. (CCH) I 99,505 (D.D.C. Sept. 23, 1983), aff d, FED. SEC. L. ReP. (CCH) I 91 ,566 (D.C. Cir. Sept. 23, 1984).

204. In re Sealed Case (Tesoro Petroleum), 676 F.2d 793 (D.C. Cir. 1982). A few weeks after publication of this opinion, the press correctly identified the subject corporation as Tesoro Petroleum Company. 
product protection, but two of the files clearly were not so protected. ${ }^{205}$ The court's conclusion was premised on the two separate principles of waiver of and exception to the work-product privilege. ${ }^{206}$

The government had an affidavit from a witness dubbed " $\mathrm{X}$ " and described as "an American citizen with business interests in a specific foreign country." 207 Witness " $\mathrm{X}$ " described a payoff in connection with a foreign contract:

Shortly after the signing of the contract in [the country where $\mathrm{X}$ does business] during the first part of Oct. 1974 I received a phone call from [a senior officer at Company]. He said they were having difficulty in arranging the pay off to [the senior official of a company owned by the foreign government] and asked me if I could get them an invoice to cover it from a company I was associated with [in the foreign country]. He said that once the . . . pay off was taken care of they would then arrange for the financing I needed for my [business].

I arranged for [the Company officer] to get the invoice he needed on the stationery of [the company I owned].

The date for the pay off was set . . . [ [The foreign official and a woman] arrived at my house about 9:30 AM. I left shortly after to pick up [Company's chairman] at the airport. I picked up [Company's chairman] at about 10:30 AM and as we were driving to my House he said that we had to stop first at the [Bank] \& pick up the money. He said that he had a check made out to [my company] and that all I had to do was endorse it because the arrangements had already been made with the Bank. I reluctantly agreed, with considerable misgivings about entering the transaction.

We arrived at the Bank where everything was ready, the money was counted out, and we left. [An associate of the chairman] was waiting in his car in front of the Bank and followed us to my House where he remained in his car. [The chairman] and I entered the House where [the woman and the official] were waiting. I placed the Briefcase containing the money on the floor. After the greetings and Handshakes [the chairman] picked up the Briefcase and opened it and said, "Here's your 200 thousand. We counted it at the Bank but we can count it again if you want." [The Chairman] then proceeded to count the money. [The official] said no, it's not necessary. [The chairman] then closed the Briefcase and handed it to [the official]. ${ }^{208}$

The court described "three successive investigations of the company's business practices and candor," i.e., separate investigations by the IRS, the SEC, and the grand jury. ${ }^{209}$ Indeed, there were really four investigations because the SEC investigation embraced both the formal SEC governmental investigation and Tesoro's defensive internal corporate self-investigation pursuant to the SEC's voluntary disclosure program. ${ }^{210}$

Tesoro had been subjected to an IRS corporate slush funds investigation, ${ }^{211}$ and

205. In re Sealed Case (Tesoro Petroleum), 676 F.2d 793, 816 (D.C. Cir. 1982).

206. Id. at 798 .

207. Id.

208. Id. (footnote omitted).

209. Id. at 799-805.

210. Id. at $801-02$.

211. For a description of the IRS illegal domestic and foreign payments program, see Dunn, Questionable Payments: A Consideration of Certain Specific Issues and A Current Overall Evaluation, 36TH ANNUAL N.Y.U. INSTTUTTE on Federal TAXation 1309 (1978). See also Chu \& Magraw, The Deductibility of Questionable Foreign Payments, 87 YALE L.J. 1091 (1978). 
the company and its executives had been subjected to "a list of 19 questions" to be answered in affidavit form. ${ }^{212}$ For some reason unknown to me, the IRS had expanded its well-known "eleven questions" (more recently "five questions") to nineteen for Tesoro. ${ }^{213}$ Tesoro executives, including the company's chairman, in answering the IRS questions admitted making payments to finders, consultants, and sales agents with respect to foreign business, but denied knowledge of bribes. Tesoro's chairman specifically averred: "To the best of my knowledge, the payments . . . were not bribes, kickbacks or other such payments to obtain favorable treatment in securing business or otherwise to obtain special concessions, or to pay for favorable treatment for business secured or for special concessions already obtained.",214 Responses from at least one Tesoro vice president also indicated that he may have received an improper reimbursement from the company for a domestic political campaign contribution. ${ }^{215}$

The SEC began a private investigation in the midst of the IRS investigation. In the initial, informal portion of the SEC investigation, Tesoro was allowed to conduct its own internal investigation as part of the SEC's voluntary disclosure program. ${ }^{216}$

The voluntary disclosure program was well developed by early 1977 , when the staff of the SEC contacted Company and suggested that it make use of the voluntary method to clear the air about any payments of questionable legality in the United States or abroad. Accordingly, Company's board of directors retained a large law firm to act as special investigative counsel and set up a special committee of independent directors to oversee the investigation. During the summer of 1977 lawyers from the firm examined hundreds of documents in Company's files and interviewed 52 persons, all officers, directors, employees, or consultants hired by the Company. ${ }^{217}$

In May 1978, special counsel submitted its payments report to Tesoro's Special Committee. While generic in content-with names of foreign nations described by code-_"the report disclosed in detail questionable business practices in six countries." 218 The report described a potpourri of suspicious details involving the company's and its chairman's dealings with the payment of $\$ 200,000$ to " $X$ " as well as a $\$ 200,000$ loan guarantee to one of " $X$ 's" companies. However, investigative counsel's report contained the following disclaimer:

No directors, officers or employees of the Company interviewed by us expressed any knowledge that either the $\$ 200,000$ payments to [" $X$ "] or the proceeds of the loan guaranteed by [Company] were used in any way to benefit personally any public officials of the foreign country .... Nevertheless, we believe that the manner and circumstances of payment and the participation therein of the Chairman of the Board . . . raise questions of irregularity which we have not been able to resolve satisfactorily, particularly in light of our inability to interview ["X"]. ${ }^{219}$

212. In re Sealed Case (Tesoro Petroleum), 676 F.2d 793, 799 (D.C. Cir. 1982).

213. See United States v. Wyatt, 637 F.2d 293 (5th Cir. 1981) (court sustains IRS “eleven questions"); United States v. Richards, 479 F. Supp. 828 (E.D. Va. 1979), aff $d, 631$ F.2d 341 (4th Cir. 1980) (court upholds narrowing of IRS “eleven questions"); United States v. Richards, 431 F. Supp. 249 (E.D. Va. 1977).

214. In re Sealed Case (Tesoro Petroleum), 676 F.2d 793, 799 (D.C. Cir. 1982) (footnote omitted).

215. Id. at 799-800.

216. See supra note 70 for a discussion of the SEC's Voluntary Disclosure Program.

217. In re Sealed Case (Tesoro Petroleum), 676 F.2d 793, 801 (D.C. Cir. 1982).

218. Id. at 801-02.

219. Id. at 802 (footnote omitted). 
The report did not explain why " $\mathrm{X}$ " could not be interviewed, nor what " $\mathrm{X}$ " supposedly did to earn a fee of $\$ 400,000$.

The investigative counsel's report also described various company disbursements "that would appear to have violated the provisions of applicable federal election laws." 220 Tesoro gave the SEC a copy of the payments report and access to much of the underlying investigative work product. Through such access the SEC staff found evidence of possible bribery in a seventh country, not covered in the report. ${ }^{221}$ On the basis of the report and its underlying investigative work product, the SEC filed an injunctive action against Tesoro. Tesoro consented to the injunction. Since the company had already conducted the internal investigation, the ancillary relief in the consent decree was quite mild-principally the appointment of one new independent director, satisfactory to the SEC, who would serve as chair of the company's audit committee. ${ }^{222}$ But the SEC injunction was not the only consequence of Tesoro's volunteerism. The SEC referred the Tesoro case to the Department of Justice for consideration of possible criminal prosecution. ${ }^{223}$ The grand jury investigation followed.

The company provided the grand jury with copies of the same documents it had provided to the SEC, ${ }^{224}$ including the investigative report. Tesoro's former general counsel turned over thirty-eight documents subpoenaed by the grand jury to the company's outside counsel defending the grand jury investigation. The grand jury then issued a subpoena to outside counsel for the documents. Both the company and outside counsel asserted attorney-client and work-product privilege. The district court rejected the government's argument that the facts established the "crime-fraud" exception to attorney-client and work-product privileges. ${ }^{225}$ However, the district court ruled that the company had waived both attorney-client privilege and workproduct protection as to portions of eight of the documents. ${ }^{226}$

Tesoro changed defense counsel in the grand jury investigation, the thirty-eight documents passed to the new outside law firm, and, "in due course, a new grand jury issued a subpoena for the documents addressed to their current possessor." 227 The

220. Id.

221. Id. at 803.

222. SEC v. Tesoro Petroleum Corp., SEC Lit. Release No. 9236, [1980 Transfer Binder] FED. SEC. L. REP. (CCH) [ 97,699 (D.D.C. Nov. 20, 1980).

223. In re Sealed Case (Tesoro Petroleum), 676 F.2d 793, 803 (D.C. Cir. 1982).

224. Id.

225. Id. at 813-14.

226. The district court found waiver based on two lines of reasoning:

First, the court held that Company's prior disclosures revealed the substance of attomey-client confidences about certain questionable payments discussed in the investigative counsel's report and interview notes. Therefore, Company had waived its attorney-client privilege with respect to the payments, and the court concluded that the purposes of the work product privilege were so closely related that waiver of the attomey-client privilege should also constitute waiver of the work product privilege. . . . Second, the District Court found that the report and notes did not contain the same wealth of relevant detail as the documents under subpoena in this case. The court characterized the version of the facts that appeared in the report as an "enchanted . . .tale," and it went on to state, "This kind of selective waiver is precisely the kind of manipulation and sl[e]ight-of-hand that led to the waiver doctrine in the first place." The District Court also rejected the govemment's argument that all of the documents under subpoena came within the "crime-fraud" exception to both privileges.

Id. at 804 n. 33 (citations omitted). The Court of Appeals rejected an appeal of the district court's denial of Tesoro's motion to quash the grand jury subpoena at that point in time. See In re Sealed Case, 655 F.2d 1298 (D.C. Cir. 1981).

227. In re Sealed Case (Tesoro Petroleum), 676 F.2d 793, 805 (D.C. Cir. 1982). 
district court held the lawyer then holding the documents in contempt for refusing to produce the eight unprivileged documents. ${ }^{228}$

The D.C. Circuit disagreed with the district court's rejection of the crime-fraud exception, and held that it clearly applied to Tesoro's conduct. Since the workproduct privilege is broader than the attorney-client privilege, and since some of the documents might be protected by work-product even if they were not attorney-client communications, the court analyzed the case primarily with regard to the workproduct doctrine. ${ }^{229}$ The court acknowledged that the work product-privilege does apply to grand jury investigations as well as to criminal discovery and agency investigations. ${ }^{230}$ It also acknowledged both the crime-fraud exception ${ }^{231}$ and the implied waiver doctrine. ${ }^{232}$ The court found that even had the crime-fraud exception not applied, some of the documents would nevertheless lose their work-product protection because of Tesoro's implied waiver:

Company entered into an arrangement with the SEC under which, as a matter of both common sense and common knowledge, Company relinquished its right to prevent the government from examining whatever documents were necessary for a fair evaluation of the final report offered to its shareholders and the SEC. Just because Company was successful in hiding crucial documents from the SEC, we need not allow Company to withhold them from a grand jury investigating possible crimes uncovered during the SEC's investigation. We do not consider whether we would imply a waiver in other types of litigation for all of Company's privileged files relating to the report. But the combination of factors in this case including the fact that some of the documents impeach the veracity of Company's purported full disclosure, makes it inconsistent with the purposes of the work product privilege to deny the grand jury access to these documents. ${ }^{233}$

The court specifically rejected the limited-waiver theory of attorney-client and workproduct privileges of the Diversified Industries case. ${ }^{234}$

Throughout the opinion, the court criticized Tesoro's "sleight-of-hand" and

228. In re Subpoena Issued in Grand Jury Investigation, Misc. No. $81-0140$ (D.D.C. June 20, 1981) (unreported). The eight documents are described at In re Sealed Case (Tesoro Petroleum), 676 F.2d 793, 805 (D.C. Cir. 1982).

229. In re Sealed Case (Tesoro Petroleum) 676 F.2d 793, 809-16 (D.C. Cir. 1982). Of course, the court began with analysis of the seminal work product case, Hickman v. Taylor, 329 U.S. 495 (1947); see also Upjohn Co. v. United States, 449 U.S. 383,389 (1981).

230. In re Sealed Case (Tesoro Petroleum), 676 F.2d 793, 806 (D.C. Cir. 1982); see also Upjohn Co. v. United States, 449 U.S. 383 (1981); United States v. Nobles, 422 U.S. 225 (1975); In re Special September 1978 Grand Jury (II), 640 F.2d 49 (7th Cir. 1980); In re Grand Jury Subpoena (John Doe, Inc.), 599 F.2d 504 (2d Cir. 1979); In re Grand Jury Investigation (Sun Co.), 599 F.2d 1224 (3d Cir. 1979); In re September 1975 Grand Jury Term, 532 F.2d 734 (10th Cir. 1976) (by implication); In re Grand Jury Proceedings (Duffy), 473 F.2d 840 (8th Cir. 1973); In re Terkeltaub, 256 F. Supp. 638 (S.D.N.Y. 1966).

231. In re Sealed Case (Tesoro Petroleum), 676 F.2d 793, 807 (D.C. Cir. 1982), citing the leading case of the "crime-fraud" exception, Clark v. United States, 289 U.S. 1 (1933), where the principle is stated as follows: "A privilege surviv[es] until the relation is abused and vanish[es] when abuse is shown to the satisfaction of the judge." Id. at 16.

232. 676 F.2d 793, 807 (D.C. Cir. 1982). The court noted:

Implied waiver deals with an abuse of a privilege itself rather than of a privileged relationship. Where society has subordinated its interest in the search for truth in favor of allowing certain information to remain conId.

fidential, it need not allow that confidentiality to be used as a tool for manipulation of the truth-seeking process.

233. Id. at 817. The court commented that "voluntary breach of confidence or selective disclosure for tactical purposes waives the privilege. Disclosure is inconsistent with confidentiality, and cours need not permit hide-and-seek manipulation of confidences in order to foster candor." $I d$. at 818.

234. Id. at 823-24; see Diversified Indus., Inc. v. Meredith, 572 F.2d 596 (8th Cir. 1977) (en banc); see also Permian Corp. v. United States, 665 F.2d 1214 (D.C. Cir. 1981). 
"manipulation" in attempting to misuse attorney-client and work-product privileges. The court quoted Judge Learned Hand in Loubriel v. United States. ${ }^{235}$

The question is no less than whether courts must put up with shifts and subterfuges in the place of truth and are powerless to put an end to trifling. They would prove themselves incapable of dealing with actualities if it were so, for there is no surer sign of a feeble and fumbling law than timidity in penetrating the form to the substance. . . ${ }^{236}$

I suggest that any counsel conducting an internal investigation read the Sealed Case opinion at least twice. A portion of its concluding paragraphs is a strong reminder of a lawyer's duty to guard against a client's manipulation:

The vitality of the adversary system is of great concern to us, as it is to ail courts, and we have due regard for the importance of privilege in maintaining that vitality. It would ill serve the adversary system, however, if we were to exalt the form of privilege over its substance. Through the doctrines of implied waiver and exception, the law entrusts the courts with a duty to guard that the offices of lawyers, and the respect which we have for the bar, are not used for unfair or corrupt purposes.

In the exercise of that duty, we have determined that there is a substantial likelihood that the multinational corporation befote us has attempted to manipulate its privilege, by withholding vital documents while making a great pretense of full disclosure of their contents. It does not deserve the protections enjoyed by those who use the adversary system for its legitimate ends. Therefore, we have held that the District Court did not err in ordering Company's attorney to disclose two portions of its former general counsel's files. . . 237

Just as the Southland matter did not end with the John Doe opinion, the Tesoro matter did not end with the Sealed Case opinion. Presumably the grand jury investigation continues. ${ }^{238}$ Derivative and class action litigation is being pursued in the Texas courts. In that Texas litigation, the U.S. District Court for the District of Columbia has just had occasion to issue another opinion respecting documents relating to the Tesoro payments investigation now held by two major Texas law firms. ${ }^{239}$ In that case Judge Oberdorfer (one of my prestigious former partners) ordered that Fulbright \& Jaworski and Vinson \& Elkins produce for plaintiffs, in private civil discovery, copies of the documents relating to Tesoro's payments investigation that had previously been produced to the SEC and to the grand jury. The documents "consist essentially of the report prepared by the lawyers summarizing their investigation of the foreign payments allegations, Tesoro documents reviewed by the lawyers, and notes of the lawyers' intervicws of Tesoro employees and others-all of which are in the hands of the SEC and the Grand Jury. "240 Once again, Tesoro and

235. 9 F.2d 807 (2d Cir. 1926).

236. In re Sealed Case (Tesoro Pelroleum), 676 F.2d 793, 825 (D.C. Cir. 1982) (quatigg id.)

237. Id. al 825 .

238. Apparenlly, the grand jury inquiry cventually terminated with a decision not to seck at criminal prosecution. $5 e t^{2}$ In re Subpoena Duces Tecum (Fulbright \& Jaworski and Winson \& Elkins, Tesoro Pelroleum Core. J. FEs. SEC. L. Rer. (CСH) 91,566 л.5 (D.C. Cir. 1984)

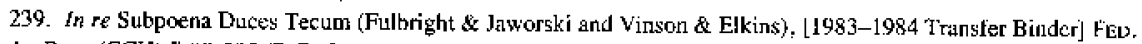
SEC. L. REP. (CCH) \| 99,505 (D.D.C. Sept, 23, 1983), aff d FED. SEC. L. Rep. (CCH) 1 91,566 (D.C. Cir, Sept. 23, $1984)$.

240. Id. at 96,931 . 
its lawyers resisted production on the basis of attorney-client and work-product privilege claims. Plaintiffs claimed that delivery of the documents to the SEC and to the grand jury "waived and fatally fractured those privileges." 241

Rejecting the limited waiver theory of Diversified Industries, ${ }^{242}$ and applying the holdings of the D.C. Circuit in both Permian ${ }^{243}$ and Sealed Case, ${ }^{244}$ Judge Oberdorfer held that voluntary disclosure to the SEC in an attempt to benefit Tesoro, waived the privileges. The court added, " $[R]$ espondents' later response to the Grand Jury subpoena had no legal consequence. Any claim that the Grand Jury transaction somehow reversed the SEC disclosure and 'put the genie back into the bottle' is untenable." 245 Tesoro had stated in producing the documents to the SEC that the production was not intended to waive attorney-client and work-product privileges. The court refused to find that the statement, absent some express confidentiality commitment by the SEC, would create a limited waiver of the work-product privilege in the circumstances of the case. ${ }^{246}$ The Court of Appeals for the District of Columbia Circuit recently affirmed Judge Oberdorfer's holding. ${ }^{247}$

\section{Citicorp and Ashland Oil}

The two separate cases of Citicorp and Ashland Oil have received a great deal of press attention recently. They deserve some comment in this article, primarily with respect to the issue of whether all internal investigations should be conducted by wholly independent outside counsel who have done no prior legal work for the corporation being investigated. Let me state clearly that I do not advocate such an extreme position in general, nor do I suggest such an approach was either necessary or appropriate in either the Ashland Oil or Citicorp matters. I mention the cases solely so that when counsel conduct internal investigations, they can attempt to structure their methodology to avoid criticism in the press. ${ }^{248}$

\section{Citicorp}

Citicorp had its regular outside counsel, Shearman \& Sterling, conduct a major internal corporate investigation of Citibank's worldwide foreign exchange activities. The investigation was ordered after a disgruntled employee (subsequently terminated) alleged that the bank had failed to comply with currency exchange laws and regulations of one or more foreign countries. ${ }^{249}$

241. Id. at 96,932 .

242. Diversified Indus., Inc. v. Meredith, 572 F.2d 596 (8th Cir. 1977) (en banc).

243. Permian Corp. v. United States, 665 F.2d 1214 (D.C. Cir. 1981).

244. In re Sealed Case (Tesoro Petroleum), 676 F.2d 793 (D.C. Cir. 1982).

245. In re Subpoena Duces Tecum (Fulbright \& Jaworski and Vinson \& Elkins), [1983-1984 Transfer Binder] FED. SEC. L. REP. (CCH) 199,505 at 96,932 (D.D.C. Sept. 23, 1983).

246. Id. at $96,931-32$.

247. In re Subpoena Duces Tecum (Fulbright \& Jaworski and Vinson \& Elkins, Tesoro Petroleum Corp.), FED. SEC. L. ReP. (CCH) I 91,566 (D.C. Cir. Sept. 23, 1984).

248. Let me disclose my bias. I recently assisted Lloyd Cutler and Bill Perlik, two of my partners, in representing Citicorp and some of its executives in congressional testimony encompassing in part a House committee's probing into the efficacy of Citicorp's intemal investigation. My partner Mike Klein and I also serve as counsel to a former officer of an Ashland Oil subsidiary who was a major witness in Ashland's 1981 internal investigation.

249. See, e.g., Rowan, The Maverick Who Yelled Foul At CitiBank, Fortune, Jan. 10, 1983, at 40. 
After receipt of the report of Citicorp's internal investigation, the SEC conducted a private investigation of the matter, and lower-level Enforcement Division staff took issue with some of the conclusions in the Citicorp report prepared for a board committee by Shearman \& Sterling. The Enforcement staff investigative attorneys recommended that the SEC institute a formal enforcement action against Citicorp despite its voluntary internal investigation. But Enforcement Director John Fedders, with the concurrence of the Director of the Division of Corporation Finance and the SEC's General Counsel, recommended that enforcement action was not warranted. The Commission accepted that nonenforcement recommendation in March 1982 and issued a release rationalizing its nonenforcement decision as follows:

1. The allegations (by the lower level investigative lawyers) were not adequately established.

2. The Comptroller of the Currency concluded that no enforcement action was warranted under U.S. banking laws.

3. The alleged amounts were not material.

4. The law concerning disclosure of unadjudicated allegations is unclear. There would have been a serious possibility of court reversal of the Commission's action which would establish bad precedent.

5. The matter was essentially a banking or tax case, not a securities case. riod. ${ }^{250}$

6. The case was stale. The questioned practices occurred in the 1973-78 pe-

Critical comment subsequently arose in the press about the SEC's decision to close down the Citicorp investigation without formal enforcement action. The Shearman \& Sterling report was harshly criticized in an American Lawyer article. ${ }^{251}$ Both Citicorp and Shearman \& Sterling refuted the criticism in subsequent congressional testimony. ${ }^{252}$ One of the inquiries raised by the House subcommittee was whether Citicorp should have chosen an outside counsel who had not previously represented the bank to conduct the internal investigation.

\section{Ashland Oil}

In 1981, Ashland Oil had the Pittsburgh law firm of Kirkpatrick, Lockhart, Johnson \& Hutchinson conduct an internal corporate investigation of various matters, including payments made to or for the benefit of a foreign promoter, Yehia Omar, in the late 1970s and in 1980-81. Chuck Queenan, the Kirkpatrick partner in charge of the investigation, had previously represented Ashland in various matters, including the conduct in the "Watergate-foreign payments" era of the mid-70s of a special investigation encompassing Ashland's domestic political contributions and its foreign payments. 253

250. SEC CitiCorp Release, SEC Release No. 82-19 (March 5, 1982); see also Freeman \& Kronstein, The Commission and the CitiCorp Case: Focus on The Legal Issue of Materiality. N.Y. L.J., Dec. 13, 1982, at 32.

251. Brill, What Price Loyalty? AM. LAw., Aug. 1982, at 8.

252. See, e.g., Fialka, Citicorp Says Probes Generally Cleared Its Mid-70s Foreign Currency Dealings, Wall St. J., June 29, 1983, at 12, col. 1; see also SEC and Citicorp, Hearings Before the Subcomm. on Oversight and Investigations of the House Comm. on Energy and Commerce, 97th Cong., 2d Sess., Serial No. 97-193 (Sept. 13 and 17, 1982). Later testimony by Citicorp officials and a Shearman \& Sterling partner before the same House Subcommittee has not yet been printed.

253. See Ashland Oil Case, supra note 39; see also Ashland Oil Investigation Report (June 26, 1975). 
In 1983, two years after Queenan prepared and Ashland's board of directors accepted the so-called Queenan Report (sometimes called the Kirkpatrick, Lockhart Report), the SEC commenced a formal private investigation of Ashland's foreign payments during the late 1970s and early 1980s, including the matters covered in the Queenan Report. ${ }^{254}$ A congressional committee has been informally pursuing its own inquiries in the Ashland Oil matter. The Queenan Report concluded that no violation of United States law had occurred and that the company had no obligation to disclose the investigation or its results. ${ }^{255}$ Questions have been raised in the press whether the Kirkpatrick firm was sufficiently independent of Ashland to conduct the internal inquiry. ${ }^{256}$

\section{Conclusion}

The important issue to consider is not whether law firms can investigate their regular clients. ${ }^{257}$ Of course they can. The issues we should ruminate about are: (i) in what peculiar types of cases should inside counsel or regular outside counsel not serve as investigating counsel; and (ii) in those instances when regular outside counsel, or inside counsel, do serve as investigating counsel, what can be done to protect the integrity and efficacy of the investigation and the report thereof from unwarranted criticism? ${ }^{258}$

Obviously, no in-house counsel or regular outside counsel or any other counsel should participate in an investigation if he or she has participated in or directly or indirectly counselled the transactions or activities which are the subject matter of the internal investigation. ${ }^{259}$ Inside counsel should not be charged with investigating corporate superiors, i.e., the board members or the principal executive officers of the company. I don't honestly know whether the latter proscription should carry over to regular outside counsel.

The ALI's first Tentative Draft of the Restatement of Principles of Corporate Governance contains a comment respecting derivative litigation which states:

Because the role of counsel is especially sensitive in internal corporate investigations and because considerable reliance on the legal advice given by such counsel is to be

254. See, e.g., Jackson, SEC is Investigating Ashland Oil Payment to Brother of Ex-U.N. Ambassador Young. Wall St. J., Nov. 21, 1983, at 27, col. 4; Ashland Oil: Trying to Cope With a Diversification Hangover and a Lingering Scandal, Business Week, Nov. 7, 1983, at 132; Ingrassia, Ashland Oil Fires McKay, Who Disclosed Payments That Prompted SEC Inquiry, Wall St. J,, Sept. 22, 1983, at 15, col. 2; Taylor, Ashland Oil Bracing For Investigation, Lexington [Kentucky] Herald-Leader, Sept. 18, 1983, at 1; Arieff, SEC, Congress Question Counsel's Role in Review of Ashland Oil Payment, Legal Times, May 30, 1983, at 1.

255. See Queenan Report at 215.

256. See, e.g., Arieff, supra note 254 , at 1.

257. Should Law Firms Investigate Their Own Clients? Business Week, July 11, 1983, at 59; cf. Noble, Business and the Law: Investigations by Lawyers, N.Y. Times, Sept. 6, 1983, at D-2, col. 1.

258. Arieff, Ethics Reviews Still Deemed Useful for Business, Legal Times, July 25, 1983, at 4; Noble, supra note 257.

259. See Queenan, Conducting Internal Investigations, in A. Levenson, A. MAthews, \& H. Pitt, ForejgN Corrupt Practices and Internal ACCOUNTING Controls 181, at 189 (1980) ("Use of regular outside counsel may well be appropriate, except in cases where he had involvement in transactions now under review.") 
presumed where the committee consists of non-lawyers, $\S 7.03$ (b)(ii) specifies that "in the absence of special circumstances" counsel who is independent of the corporation should be chosen to coordinate and advise such an investigation. . . ${ }^{260}$

The ALI project's definition of "special counsel" in such situations excludes inhouse counsel, regular corporate counsel, and any other counsel "who have already advised with respect to the transaction, even if they are not regular counsel, since they have prejudged the issues." 261

I do have one suggestion, though, in cases where one can predict in advance the possibility of hindsight judgment of third parties raising questions about an alleged appearance of a lack of independence after the internal investigation is over, the investigative report filed, and the fact of the investigation and the report's conclusions public. At the planning stage, when structuring the methodology of the internal investigation, counsel and the corporate client might consider providing for the selection of a wholly disinterested, independent special review person who will, in effect, investigate the investigator and the report, and issue a "Good Housekeeping seal of approval" to the internal corporate investigation. I do not mean a consulting counsel who participates in planning and conducting all or portions of the actual investigation (i.e., the limited role John Fedders and Arnold \& Porter played in Southland). Rather, I mean a special review person who is retained after the investigation is over and the report is prepared but before the board committee signs off in accepting the report. The special review person would do what the SEC Enforcement staff did in the voluntary program-review the methodology and examine the underlying investigative work product to assure that the investigation was complete and that the report is both accurate and complete. My colleague Judd Best at Steptoe \& Johnson, who has conducted a few of these investigations, found that procedure wholly satisfactory in the Page Airways case, ${ }^{262}$ and the SEC has used that mechanism in several other cases. ${ }^{263}$ As Judd Best has told me more than once, "The special review person concept preserves for the internal investigative process a public perception of independence and fairness. And it keeps the troops at the SEC from being restless!" 1982).

261. Id. at 320 .

262. See Page Airways Case, supra, note 57.

263. See, e.g.. SEC v. Anheuser-Busch, Inc., SEC Lit. Release No. 7930 (D.D.C. May 20, 1977) at 12 SEC Docket No. 6 at 502 (June 6, 1977); IT \& T Case, supra note 54; Schlitz Case, supra note 62; SEC v. ForemostMcKesson, Inc., SEC Lit. Release No. 7479 (D.D.C. July 7, 1976) at 9 SEC Docket No. 20 at 1074 (July 21, 1976). 
Al Sommer may have labelled the internal corporate investigation an extra-legal institution. ${ }^{264}$ I submit that it is gradually becoming fully legitimized. Now the task of the Bar and our corporate clients is to use the mechanism fairly and efficaciously, ${ }^{265}$ to assure that neither the SEC, nor Congress, nor the courts will take this self-policing technique away from us. ${ }^{266}$

264. Sommer, supra note 1 , at 505 .

265. Corporations that have attempted to utilize the internal investigation technique as a cover-up or to produce a misleading whitewash report have not fared very well. A good illustration is the case of SEC v. Zale Corp., SEC Lit. Release No. 8081 (N.D. Tex. Aug. 24, 1977) at 12 SEC Docket No. 19 at 1592 (Sept. 6, 1977) [hereinafter cited as Zale Case].

At issue in the Zale case were allegations by a former treasurer of the corporation that the company had systematically violated United States and foreign tax laws, and had split the spoils between the corporation and management. To evaluate these charges, which centered on the corporation's chairman, the Zale board relied on an investigation conducted principally by the chairman's son. Although the independent committee charged with conducting the investigation was composed of outsiders . . . the SEC concluded that it had failed to conduct a meaningful independent investigation. When increasing pressure led the committee to attempt a fuller investigation, the full board interfered and eventually abolished the committee.

Coffee, supra note 42 , at 1236 . As a result, the SEC sued Zale Corp. in a civil injunctive action. In a consent injunctive decree, Zale was required to restructure its audit committee, add a number of new, outside, independent directors to its board, provide adequate training for new directors, and take other precautionary measures. The audit committee was empowered to investigate management and press claims against any members thereof. The company was also required to adopt a corporate code of ethics. Zale Case, supra; see also SEC v. Zale Corp., 650 F.2d 718 (5th Cir. 1981).

The SEC has conducted several independent investigations in various cases (in addition to the Southland and Tesoro Petroleum cases) to test the adequacy of prior internal corporate inquiries. See, e.g., PepsiCo, Inc. v. SEC, 563 F. Supp. 828 (S.D.N.Y. 1983); IT\&T Case, supra note 54; Brown, SEC Study Aimed At PepsiCo Probe Into Accounting, Wash. Post, June 1, 1983, at C-7, col. 5; Guyon, PepsiCo, SEC Spar Over Probe of Overseas Net; Overstatements for 5 Years Studied; Firm is Seeking Subpoena Notification. Wall St. J., June 1, 1983, at 5, col. 1; see also SEC v. International Tel. \& Tel. Corp. [1978 Transfer Binder] FeD. SEC. L. REP. (CCH) I 96,452 (D.D.C. May 26, 1978) (order denying motion to seal complaint), [1978 Transfer Binder] FED. SEC. L. ReP. (CCH) I 96,586 (D.D.C. May 4, 1978) (full text of complaint); Brownstein, Bribery Lessons, Nat'l L.J., Oct. 1, 1983, at 2019 (suit by shareholder Ruth Blecker against IT\&T alleging inadequacy of IT\&T's internal foreign payments investigation).

266. This paper dwells on internal corporate investigations involving SEC enforcement actions and compliance with the federal securities laws. But the internal investigation is often utilized as well by corporations in a number of other regulatory areas. See, e.g., Westmoreland v. CBS, Inc., 97 F.R.D. 703 (S.D.N.Y. 1983) [investigatory report covering allegedly libelous television program]; Lowenstein, Charter Co. Conducting In-House Study of Crude-Oil Trades With Marc Rich \& Co., Wall St. J., Sept. 28, 1983, at 6, col. 2; Hughey, Alabama Flap-Olin's Handling of Kickback Allegation Enriches Informer and Raises Questions, Wall St. J., Sept. 6, 1983, at 58, col. 1. 